\title{
Reconstructing the heterogeneity of past woodlands in anthracology using the spatial distribution of charcoals in archaeological layers: Applied to the postglacial occupation of the Abeurador cave (Hérault) in the South of France
}

\author{
Lucie Chabal $^{\mathrm{a}, *}$, Christine Heinz ${ }^{\mathrm{b}}$ \\ a ISEM, Université de Montpellier, CNRS, IRD, EPHE, Place Eugène Bataillon, CC 065, 34095, Montpellier Cedex 5, France \\ ${ }^{\mathrm{b}}$ AMAP, CIRAD, CNRS, Université de Montpellier, IRD, INRA, 2196 Boulevard de la Lironde, 34398, Montpellier Cedex 5, France
}

\section{A R T I C L E I N F O}

\section{Keywords:}

Palaeoecology

Forest dynamics

Distribution pattern

Early Holocene

Younger Dryas

Mesolithic

\begin{abstract}
A B S T R A C T
Previous methodological developments in the field of anthracology have led to the definition of rigorous sampling methods in archaeological contexts, which provide highly accurate and reliable taxonomic frequency spectra as a basis for understanding past woodland vegetation. However, the fuelwood taxon frequency spectra represent a synthetic picture of forest composition in the environs of an archaeological site. Our aim in this paper is to describe the heterogeneity of woodland distribution. The Abeurador cave (Hérault) in the south of France, has previously provided an exceptionally rich palaeoecological study. We further explore the spatial frequency distributions of the charcoal taxa found in charcoal scatters from two layers dated to the Mesolithic (Preboreal). The frequencies of abundant taxa have a unimodal distribution in the sampled grid squares, close to the normal distribution. The ratio $\mathrm{s} 2 / \mathrm{m}$ (variance/mean) termed the 'distribution index', estimates the regularity of distribution of each taxon in the grid squares. We hypothesized that the frequency distribution of a taxon in a layer could be considered to be its statistical sampling distribution (i.e. probability distribution) in the firewood collection catchment at a given time, since the quantity of this taxon fluctuates in each firewood assemblage according to its probability of collection, relating to its distribution heterogeneity (or accessibility) in the past environment. The distribution index was then used to estimate the heterogeneity of the palaeoenvironmental distribution of each taxon and thus its random, uniform or clustered distribution. On this basis, we propose a mapped restitution of the evolution of the main woodland species in the surroundings of the Abeurador during the Early Holocene, integrated with the whole sequence dynamics.
\end{abstract}

\section{Aim of the study}

Methodological developments in anthracology currently provide stable and reliable datasets which are representative of past environments. This method has been shown to give complete, repeatable and consistent data, as it provides (i) a large number of woody species of all types, (ii) reproducible observations across the synchronous strata of a given site, and (iii) anthracological taxon frequency spectra with high ecological consistency (Chabal, 1997). These achievements are entirely dependent on the appropriate field sampling of charred firewood remains found in archaeological contexts and quantification methods. A broad spatial sampling of 250-400 scattered charcoals in long-term deposits, avoidance of concentrations (short-term activity) regardless of charcoal abundance and finally recovery through sieving are necessary for the frequency spectrum of taxa to have a paleoecological representativity (Chabal, 1982, 1991, 1992, 1997; 1992; Badal Garcia, 1990, 1992; Heinz, 1990b; Théry-Parisot et al., 2010a; Kabukcu and Chabal, this issue). The burning, dispersing and crushing of charcoal resulted in the disappearance (rather than accumulation) of most of the remains into ashes or microfragments, causing a synthetic effect.

Based on these methods, the palaeoecological representativeness of the frequency spectra of taxa is now well established (Chabal, 1992, 1997; Théry-Parisot, 2001; Théry-Parisot et al., 2010a). It is generally accepted that for most activities involving the use of firewood, the species present in the environment have been used in proportion to their abundance in the local environment. The taxonomic frequency spectrum

\footnotetext{
* Corresponding author.

E-mail addresses: lucie.chabal@umontpellier.fr (L. Chabal), christine.heinz@umontpellier.fr (C. Heinz).
} 
thus provides a synthetic picture of woodland composition in the fuelwood catchment proximate to the site at the time of its inhabitation. The current biological characteristics and ecological preferences of extant species can then be used to interpret their past distributions, in particular their migrations in response to climate change or their dynamics related to human activities, leading to new ecological trajectories.

So far, however, in palaeoecological reconstructions, the precise distribution of the vegetation proximate to a sampling site is usually not accurately reconstructed. In anthracology, the assumptions on which the reconstruction of local woodland vegetation spatial distribution is based are often reliable because they draw on the topographical, hydrographic or geological characteristics of the present-day environment of the site, which may not have changed significantly with the passage of time. But this is only possible if the recorded species have sufficiently strong ecological preferences (e.g. soil moisture requirements) that permit positioning them accurately in space. For other species exhibiting wider ecological tolerances and requirements, there is always the risk of equifinality when interpreting their past spatial distributions (i.e. the same species could have been distributed in different types of habitats in the past compared to its present-day ecology in the same area). Moreover, the degree of heterogeneity of past landscapes, which depends on dynamic succession processes, is often unknown, thus prohibiting the spatial positioning of certain types of woodland vegetation, since: (i) the climatic and environmental conditions of a site, including soil conditions, may have changed, (ii) the species composition of past woodland communities may have differed from that of modern or historical ones due to the expansion or contraction of individual species ranges, competitive dynamics involving interspecific facilitation, tolerance or inhibition and disturbance factors, and (iii) the ecological plasticity of species has enabled them to develop in biotopes different from those in which they are currently found. Even now, it is often possible to observe that certain species may be absent from otherwise suitable habitats due to local extinctions and/or limited dispersal, while being regularly present in unsuitable habitats, if immigration from productive source areas is sufficiently large (Pulliam, 2002). In addition, in anthracology, dominant charcoal taxa such as Juniperus, Quercus or Pinus are often not identified to species level but only to genus or, at best, species groups. This further limits our palaeoecological understanding of the woodland communities involved and their species composition, spatial distribution and environmental fit.

In this study, we propose to address these difficulties of spatial interpretation as a whole. We provide a method to find out the degree of heterogeneity of the spatial distribution of certain taxa in the site environment at a given period of time, in order to facilitate the interpretation of their actual location in the surrounding area. We also set out to investigate whether our anthracological datasets hold information on the spatial distribution of past woodlands. In classic anthracological approaches, the mean frequencies of the charcoal taxa found in an archaeological layer are used for interpreting past woodland composition. Our working hypothesis was that any variation observed in the spatial distribution of the taxon frequency spectra, across the grid squares of a given archaeological layer, may represent fluctuations in their sampling by humans as part of day-to-day firewood collection sessions. In other words, could the spatial distribution of taxon frequencies in a layer reflect the heterogeneity of past woodlands, assuming that fluctuations in the collection of wood from each species reflect the heterogeneity of its distribution (or its accessibility) in the site environs, which in turn is reflected in fluctuations observed in the accumulation and dispersal of its charred debris in the archaeological layer? In order to test this hypothesis, we analysed the anthracological assemblages available from two successive Mesolithic strata of Abeurador cave (Hérault) in the south of France, which had previously provided an exceptionally detailed reconstruction of Mesolithic woodland composition (Heinz, 1990a, 1990b).

\section{Present and past setting of the Abeurador cave}

\subsection{Location and archaeology}

Abeurador cave is located in the south of France (560 $\mathrm{m}$ a.s.1.), on the southern slope of the Montagne Noire $\sim 50 \mathrm{~km}$ from the current coastline of the Mediterranean, on a dry limestone plateau overlooking the plains of Aude (Fig. 1). The local topography is characterized as a hilly plateau system that rises locally to $640 \mathrm{~m}$ a.s.l., dissected by ravines, which slopes down to the plain $3 \mathrm{~km}$ to the south-east. The cave opens just under the edge of a limestone platform, incised by a large ravine: the 'Rec des Tremouls', a seasonal stream that runs $\sim 100 \mathrm{~m}$ below the cave level.

The cave comprises an elongated chamber of $\sim 90 \mathrm{~m} 2$ accessed through a small collapsed corridor. The depth of its stratigraphy reaches $4 \mathrm{~m}$ in the Central sector of the cave. It was occupied between $\sim 16,000$ and 4000 cal BC, during the Upper Palaeolithic, Epipalaeolithic, Early and Middle Mesolithic and, following a stratigraphic hiatus, the Early and Middle Neolithic periods (Vaquer and Barbaza, 1987; Vaquer and Ruas, 2009). Occupation of the cave might have been seasonal and during the Palaeolithic it appears to have been sporadic. Its rich archaeological record includes evidence of a subsistence economy based on hunting, fishing and gathering, with much evidence of the exploitation of plants including legumes (Fabaceae) and fruits, from as early as the Mesolithic period (Vaquer and Ruas, 2009).

Radiocarbon age determinations for the various occupation phases were sourced from Vaquer and Ruas (2009). All dates were recalibrated with OxCal 4.3 (Table 1). Palaeoclimatic phasing for the Tardiglacial and Holocene refers to the Blytt-Sernander nomenclature established for northern Europe, updated by further studies and recent ice core stadi$\mathrm{al}$ /interstadial chronologies (Rasmussen et al., 2014). Depending on the cited sources, we use cal BC dates in reference to archaeology, cal BP dates for climatic or palynological references and some ka BP or b2k dates.

\subsection{Current climate and vegetation}

Abeurador cave is situated in a rugged area, at the interface of the Upper Mesomediterranean and Supramediterranean bioclimatic zones (Fig. 2). Annual rainfall ranges from 500 to $800 \mathrm{~mm}$ and temperatures from $-5{ }^{\circ} \mathrm{C}$ to $37{ }^{\circ} \mathrm{C}$. Currently, the composition of the vegetation around the cave is determined by water availability and soil thickness. To the north of the site, above $600 \mathrm{~m}$ a.s.l. and under slightly higher rainfall, the Supramediterranean stage is marked by rather dense stands of Quercus pubescens mixed with Quercus ilex, Acer monspessulanum, Acer campestre, Sorbus aria and other tree/shrub species (Heinz, 1990a). Quercus petraea is rare and hybridizes with Quercus pubescens. Some of the species present in the Abeurador anthracological diagram currently only exist at higher altitudes, since they were cleared at lower altitudes after the Middle Neolithic. Currently, a low but fairly dense matorral

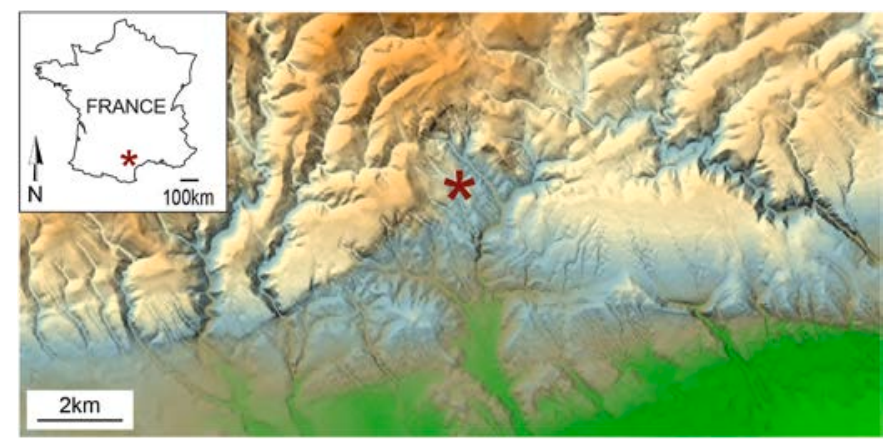

Fig. 1. Location of the Abeurador cave (Félines-Minervois, France) at a regional scale (IGN Geoportail relief map 2018). 
Table 1

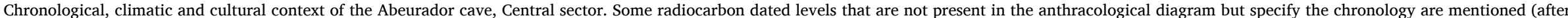

\begin{tabular}{|c|c|c|c|c|c|c|c|c|c|c|c|c|}
\hline $\begin{array}{l}\text { Anthracological } \\
\text { phase }\end{array}$ & Level & Anthracology & $\begin{array}{l}\text { Lab. } \\
\text { reference }\end{array}$ & $\begin{array}{l}\text { AMS/ } \\
\text { Conventional }\end{array}$ & $\begin{array}{l}\text { Dated material } \\
\& \text { taxon }\end{array}$ & $14 \mathrm{C} B \mathrm{P}$ & $\begin{array}{l}\text { Age cal BC 95\% } \\
\text { (OxCal 4.3) }\end{array}$ & Age cal B.P. & $\begin{array}{l}\text { Bioclimatic } \\
\text { period }\end{array}$ & Climate & $\begin{array}{l}\text { Prehistory } \\
\text { period }\end{array}$ & Culture (lithics) \\
\hline \multirow[t]{4}{*}{ Phase 2} & C2af & yes & - & & - & - & - & - & Atlantic & $\begin{array}{l}\text { Temperate (warm } \\
\text { and moist) }\end{array}$ & $\begin{array}{l}\text { Middle } \\
\text { Neolithic }\end{array}$ & $\begin{array}{l}\text { Classic } \\
\text { Chassey }\end{array}$ \\
\hline & C2ac & yes & - & & - & - & - & - & Atlantic & $\begin{array}{l}\text { Temperate (warm } \\
\text { and moist) }\end{array}$ & $\begin{array}{l}\text { Middle } \\
\text { Neolithic }\end{array}$ & $\begin{array}{l}\text { Early } \\
\text { Chassey }\end{array}$ \\
\hline & C2bc & yes & MC-2145 & Convent. & charcoal & $\begin{array}{l}6260 \pm \\
90\end{array}$ & $5466-5000$ & $7416-6950$ & Atlantic & $\begin{array}{l}\text { Temperate (warm } \\
\text { and moist) }\end{array}$ & Early Neolithic & Epicardial \\
\hline & C2bf & yes & - & & - & - & - & - & Atlantic & $\begin{array}{l}\text { Temperate (warm } \\
\text { and moist) }\end{array}$ & Early Neolithic & Epicardial \\
\hline \multirow[t]{6}{*}{ Phase 1b } & CX & yes & Gif-6745 & AMS & charcoal & $\begin{array}{l}8470 \pm \\
90\end{array}$ & 7703-7309 & 9653-9259 & Boreal & Warming & $\begin{array}{l}\text { Middle } \\
\text { Mesolithic }\end{array}$ & $\begin{array}{l}\text { Sauveterian } \\
\text { (Montclusian) }\end{array}$ \\
\hline & C3 & yes & - & - & - & - & - & - & Boreal & Warming & $\begin{array}{l}\text { Middle } \\
\text { Mesolithic }\end{array}$ & $\begin{array}{l}\text { Sauveterian } \\
\text { (Montclusian) }\end{array}$ \\
\hline & C4 & yes & - & - & - & - & - & - & Boreal & Warming & $\begin{array}{l}\text { Middle } \\
\text { Mesolithic }\end{array}$ & $\begin{array}{l}\text { Sauveterian } \\
\text { (Montclusian) }\end{array}$ \\
\hline & C5b & yes & MC-2144 & Convent. & charcoal & $\begin{array}{l}8740 \pm \\
90\end{array}$ & 8199-7592 & $10,149-9542$ & Early Boreal & Warming & $\begin{array}{l}\text { Middle } \\
\text { Mesolithic }\end{array}$ & $\begin{array}{l}\text { Sauveterian } \\
\text { (Montclusian) }\end{array}$ \\
\hline & C6 & yes & - & - & - & - & - & - & $\begin{array}{l}\text { Late } \\
\text { Preboreal }\end{array}$ & Warming & $\begin{array}{l}\text { Middle } \\
\text { Mesolithic }\end{array}$ & $\begin{array}{l}\text { Sauveterian } \\
\text { (Montclusian) }\end{array}$ \\
\hline & C7 & yes & - & - & - & - & - & - & $\begin{array}{l}\text { Early } \\
\text { Preboreal }\end{array}$ & Warming & Mesolithic & $\begin{array}{l}\text { Early } \\
\text { Sauveterian }\end{array}$ \\
\hline \multirow[t]{5}{*}{ Phase 1a } & $\begin{array}{l}\text { F8/ } \\
\text { C8 }\end{array}$ & no/yes & Gif-6746 & AMS & charcoal (F8) & $\begin{array}{l}10,480 \\
\pm 100\end{array}$ & $10,712-10,114$ & $12,662-12,064$ & $\begin{array}{l}\text { Younger } \\
\text { Dryas }\end{array}$ & Cold and dry & Epipalaeolithic & $\begin{array}{l}\text { Late } \\
\text { Azilian }\end{array}$ \\
\hline & F8b & no & $\begin{array}{l}\text { LYON-951 } \\
\text { (OXA) }\end{array}$ & AMS & $\begin{array}{l}\text { seeds } \\
\text { (Juniperus cf. } \\
\text { sabina) }\end{array}$ & $\begin{array}{l}11,090 \\
\pm 90\end{array}$ & $11,151-10,797$ & $13,101-12,747$ & Late Allerød & $\begin{array}{l}\text { Mild temperate } \\
\text { (warm and moist) }\end{array}$ & Epipalaeolithic & $\begin{array}{l}\text { Early Azilö̈ } \\
\text { (Valorguian) }\end{array}$ \\
\hline & C9 & yes & - & - & - & - & - & - & Allerød? & $\begin{array}{l}\text { Mild temperate } \\
\text { (warm and moist) }\end{array}$ & Epipalaeolithic & $\begin{array}{l}\text { Ancient Aziloid, } \\
\text { (Valorgian facies) }\end{array}$ \\
\hline & C9a & no & - & - & - & - & - & - & - & - & $\begin{array}{l}\text { Upper } \\
\text { Palaeolithic }\end{array}$ & Late Magdalenian \\
\hline & C10 & yes & - & - & - & - & - & - & Bølling? & $\begin{array}{l}\text { Mild temperate } \\
\text { (warm and moist) }\end{array}$ & $\begin{array}{l}\text { Upper } \\
\text { Palaeolithic }\end{array}$ & $\begin{array}{l}\text { Late } \\
\text { Magdalenian }\end{array}$ \\
\hline
\end{tabular}




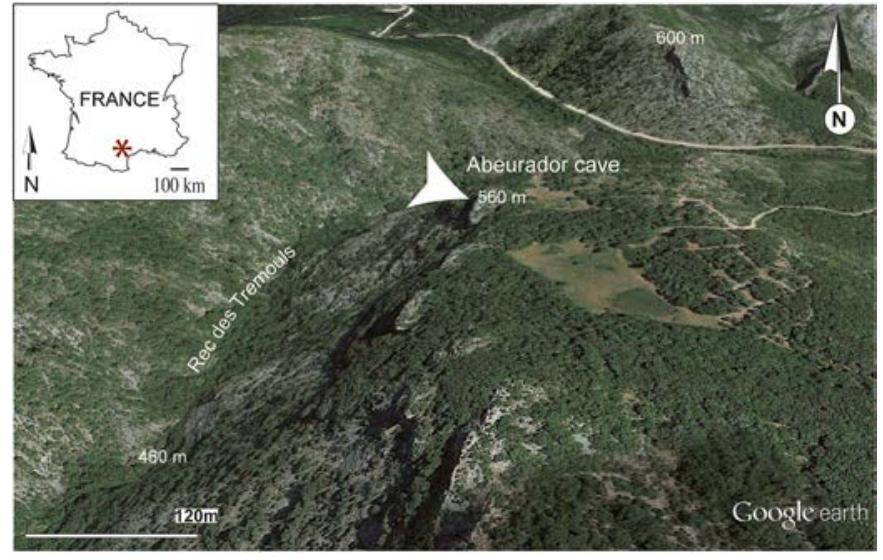

Fig. 2. The Abeurador cave in its current topographical and vegetal environment (Goodle Earth aerial view 2019).

dominated by holm oak covers the surroundings of the cave, the thalwegs, the ravines, the underside of the limestone ledges where run-off water flows and some of the flat areas of the plateau system where erosion is limited. Quercus pubescens, Juniperus communis, Erica arborea, Calluna vulgaris, are present on schists, with a low active lime content and better water retention. Junipers include Juniperus communis subsp. communis, J. phonicea and Juniperus oxycedrus. On the slopes and the most eroded flat areas, low, dry scrubland includes Juniperus oxycedrus and other shrub species, revealing, in some places, the bare rock beneath. Water-dependent species are now found several kilometres south in the lowlands.

These rather homogeneous and dry woodlands do not represent the biogeographic potential of the region, as they reflect centuries of fire, soil erosion and over-exploitation. Despite this, most of the species of the past can be found in this diminished vegetation, with few exceptions such as Pinus type sylvestris.

\subsection{The context of anthracological study}

Abeurador cave has provided a long sequence of well-preserved charcoal material, originating from the Central sector, which has enabled the detailed application of appropriate sampling and laboratory methods (see section 1.) and the reconstruction of long diachronic vegetation histories (Heinz, 1990a, 1990b; Heinz et al., 1992; Heinz and Thiébault, 1998). The anthracological diagram shows three main phases in the local vegetation history, from the Upper Palaeolithic through to the Middle Neolithic (Fig. 3).

Microscopic identifications of wood charcoal are often to genus level, more rarely to species (or species group within a genus). More specifically:

- Within the pines it is possible to identify Pinus type sylvestris i.e. either Pinus sylvestris, Pinus nigra (i.e. P. nigra subsp. salzmannii) or Pinus mugo sspp. (Roiron et al., 2013). Pinus sylvestris is the species most likely to have spread during postglacial periods, although nothing excludes the presence of other species at lower frequencies. We have assumed that only Pinus sylvestris was present at Abeurador.

- Quercus deciduous was most probably mainly Quercus pubescens, the current dominant deciduous oak in the Mediterranean region, but other deciduous oak species cannot be excluded, especially Quercus petraea.

- Juniperus can include several species, which, to date, cannot be differentiated on the basis of wood anatomy alone. Nevertheless, at Abeurador, thousands of carbonized remains from the seeds/fruits of Juniperus sabina, J. communis cf. subsp. nana, J. communis cf. subsp. communis and $J$. thurifera, were identified from the Middle
Magdalenian to the Middle Mesolithic (Heinz et al., 1992; Vaquer and Ruas, 2009) (see section 5.). At the Cova de Cendres (Spain), $J$. sabina, J. oxycedrus, $J$. cf. communis and $J$. cf. thurifera were also found in the Middle/Upper Magdalenian, interpreted as an open landscape in a cold continental climate (Martínez Varea and Badal Garcia, 2018).

\subsection{Climatic and anthracological phasing}

\subsubsection{Phase $1 a$}

According to its radiocarbon date (Table 1), the basal layer of the sequence (C10b) dates from the Oldest Dryas, which is consistent with the microfauna indicating very harsh conditions. No charcoal data were available from C10b. According to lithics, this level dates from the Middle Magdalenian (Mistrot, 2001; Vaquer and Ruas, 2009). The anthracological diagram starts just after, in C10. According to archaeological lithics and radiocarbon dates, Phase 1 includes three levels: an Upper Palaeolithic (C10), not distinctive from a cultural point of view, and two Epipalaeolithic (C9: Ancient Aziloid; C8: Late Azilian) levels. In C10 and C9, both anthracological spectra are co-dominated by Pinus type sylvestris, Juniperus and deciduous oak forest taxa, which indicates a mild climate. In C9, the microfauna also indicates undoubtedly mild temperate conditions (Vaquer and Ruas, 2009). As C9a (with no charcoal data), which comes between $\mathrm{C} 10$ and $\mathrm{C} 9$, is attributed to the Upper Magdalenian (according to the lithics), and as C10 does not show a cold climate like C10b, C10 has also been attributed to the Upper Magdalenian. Since the transition between the Upper Magdalenian (C10, C9a) and the Epipalaeolithic (C9) dates back to $\sim 14,000$ cal BP (Langlais et al., 2012), which is very close to the transition date between the Bølling and Allerød oscillations, it must be assumed that C10 could date from the Bølling and C9 from the Allerød. According to the studies based on the Greenland Ice Core Chronology 2005 (GICC05) in the North Atlantic region (Rasmussen et al., 2014), the Bølling-Allerød chronozone (originally defined by Iversen from terrestrial records in Denmark) can be used as a synonym for DO-1 (Dansgaard-Oeschger events), i.e. as a non-archive-specific name for the generally mild climate period approx. 14.6-12.9 ka b2k.

The transient warming of the Bølling-Allerød (mild and humid), which lasted for $\sim 1700$ years, was suitable for the early establishment of a temperate forest. The presence of an oak forest attested from as early as the Upper Palaeolithic, in layers C10 and C9 (Bølling-Allerød) by the frequency of deciduous oak (20\%), with Acer campestre, several species of Prunoideae and Mediterranean elements as Phillyrea, was interpreted as an indicator of local favourable microhabitats representing woodland refugium areas, in the surroundings of the Abeurador cave (Heinz and Thiébault, 1998). The southern slopes of the site, exposed to the sun around $300 \mathrm{~m}$ a.s.l. and protected to the north by the relief, may have provided a beneficial microclimate.

Epipaleolithic level (F8b) dates from the Late Allerød (without charcoal data). Layer C8, which marks the end of the Lateglacial period, is well dated to the Younger Dryas (Table 1), which in western Europe marks a period of strong climate cooling. According to Rasmussen et al. (2014), the Younger Dryas can be used as a non-archive-specific synonym for the stadial period between the Bølling-Allerød and the Holocene (approx. 12.9-11.7 ka b2k). At Abeurador, this cooling is responsible for a sharp rise in the frequencies of Pinus type sylvestris, which peak just before the Holocene warming, a slight decrease of Juniperus and a strong decline of the oak woodland taxa (Quercus deciduous, Acer and Prunoideae).

\subsubsection{Phase $1 b$}

Phase 1b starts in the Early Sauveterian, during the Mesolithic (Preboreal), at the outset of the Holocene warming, and ends in the Middle Mesolithic (Boreal). From C7 to CX, Juniperus is dominant, Pinus type sylvestris strongly declines and Quercus deciduous increases gradually. Temperatures at the start of the Holocene were warmer than at 


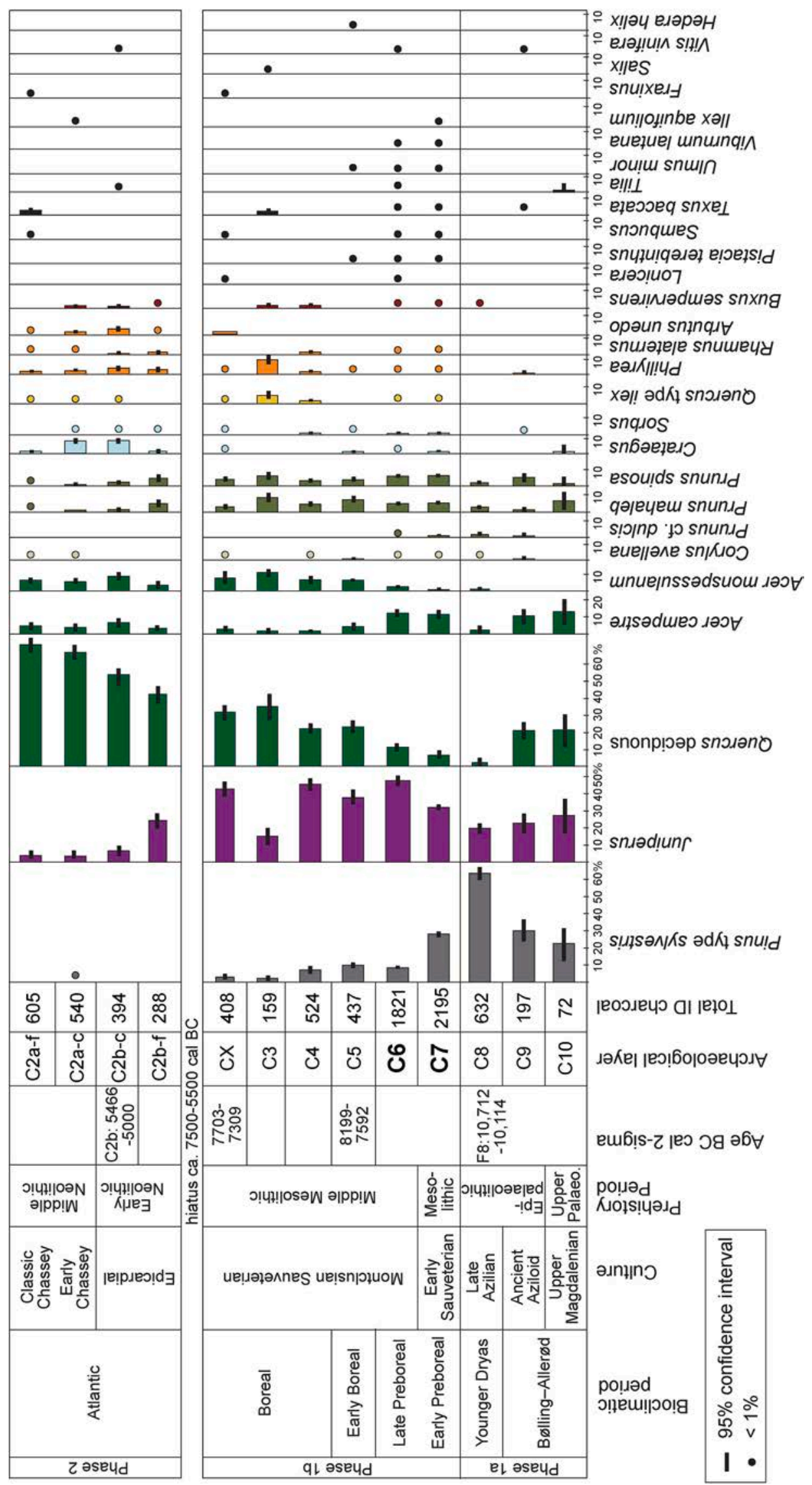

Fig. 3. Anthracological diagram of the Abeurador cave (after Heinz, 1990a, 1990b). 
present, due to an increase in insolation (Petit et al., 2002). However, the scientific consensus is that there were large spatial variations worldwide in temperature increases during the Holocene and in the time it took to reach typical Holocene conditions. In Europe, according to pollen data, Mauri et al. (2015) has shown that warming intensified and reached eastern Europe and France at $8 \mathrm{ka}$ BP (i.e. $\sim 8900 \mathrm{cal} \mathrm{BP}$ ) peaking at $\sim 7 \mathrm{ka}$ BP (i.e. towards the end of the Mesolithic). Evaluating temperature increase depends on the types of investigated proxies. According to Kaufman et al. (2020) they all indicate warming trends during the Early Holocene, some peaking as early as $\sim 10,000$ years ago (e.g. chironomids) but others (e.g. pollen) not until $\sim 6000$ years ago.

At Abeurador, temperatures possibly rose slowly throughout Phase $1 \mathrm{~b}$ for several millennia. However, from the onset of the Early Holocene Pinus type sylvestris declined rapidly, indicating that this species could no longer sustain rising temperatures at this altitude. The slow progression of deciduous oak woodland does not necessarily reflect a correlative slow increase in temperature. Deciduous forests might have struggled to reclaim an area that had been largely deforested by the previous cold conditions and the ongoing decline of pine. The establishment of Juniperus shrubs probably facilitated the expansion of deciduous Quercus forest by sheltering acorn seedlings. Several species of juniper were very well adapted to open and dry habitats. Prunus spinosa and other Rosaceae, which may represent the first cold-adapted bushes (Heinz and Barbaza, 1998), and then pioneer shrubs that precede deciduous Quercus in an ecological succession, remain at Abeurador the constant background to the development of the oak forest until the Neolithic, but in a rather discrete manner compared to other sites occupied from the Mesolithic period (Heinz and Barbaza, 1998; Henry et al., 2013).

Throughout Europe, at the start of the Holocene, coniferous forests were replaced by deciduous forests as a result of both global warming and the ongoing northward migration of hardwood species ranges. At Abeurador, an interesting comparison can be drawn between the frequency curves of two maple species, both elements of the deciduous forest (Fig. 3). The rate of Acer campestre is highest, first in the oak forest during the Bølling-Allerød and later in the Early Preboreal, decreasing during the Boreal. This species adapted to a mild temperate and/or humid climate during the thermal oscillation was disadvantaged by the climate warming so long as the Holocene hardwood forest remained relatively open. It reestablishes itself, at a lower rate, in the mature and protective deciduous oak forests of the Atlantic period. A. monspessulanum, a more xerophilic species, was not adapted to a relative coolness and thus developed from the Boreal period only. Both A. monspessulanum and A. campestre seem to be well adapted during the Atlantic in high oak forests, alongside Mediterranean species. These observations make it possible to note that the oak forest that became established from C5 in the Early Boreal was very close to the current Supramediterranean oak groves, as we know them today under Mediterranean climate conditions. This change in forest composition could mark the advent of a climate with a more pronounced summer season during the Boreal, around 8199-7592 cal BC (Table 1). However, some Mediterranean taxa appeared earlier, first in C9 (Phillyrea) probably during the Bølling-Allerød, then from the Early Preboreal in C7 onwards (Quercus type ilex). Arbutus unedo appears from the Boreal (CX) at the end of the Middle Mesolithic, at a time of advanced global warming. It is then present continuously during phase 2/Atlantic period (Neolithic), probably favoured by its ability to resprout after cutting. At Fontbregoua in Provence (France), Arbutus unedo is present since the Preboreal and in a continuous curve during the Boreal and Atlantic (Thiébault, 1997). In a general way, in France, Mediterranean species appear since the Early Preboreal, i.e. ca. 9000 BP (Henry et al., 2013). In the Iberian Peninsula, Arbutus unedo is found early, at different periods depending on the region, e.g. during the LGM period in charcoal from a refuge of Portuguese Extremadura, with Olea (Figueiral and Terral, 2002), during the Mesolithic in Portugal (Monteiro, 2013), in north-east Spain in the form of fruits (Buxo, 2008; Alcalde and Saña, 2017) and in south-east Spain in charcoal (Uzquiano et al., 2016). According to Quézel and Médail (2003) during the Early Holocene warming around the Mediterranean basin, the thermophilic and sclerophyllous species spread from refuges, after the Supramediterranean deciduous oak species, but within these forests, progressively and asynchronously. Nevertheless, in some regions as the Ebro valley in Spain, Arbutus unedo is not found before the Neolithic period (Alcolea Gracia, 2017). At the Cova de les Cendres (Alicante), in southeast Spain, Arbutus unedo is missing in charcoal before the Neolithic (Badal and Carrión, 2001; Aranbarri et al., 2020), even if a seed of 'cf. Arbutus unedo' was found much earlier in this cave, during the Middle Magdalenian (Martínez Varea and Badal Garcia, 2018). Like Ribeiro et al. (2019) in the case of Portugal, it can be assumed that in some regions, Arbutus unedo populations suffered from competition with oaks and only increased when the mature oak forest was replaced by an open forest.

\subsubsection{Phase 2}

Phase 2 comes after a stratigraphic hiatus and extends from the Early Neolithic to the Middle Neolithic, during the Atlantic bioclimatic period. Quercus deciduous becomes dominant, at the expense of Juniperus. A small increase of Mediterranean trees and shrubs is discreet compared to the current environment of the cave, especially Quercus type ilex. This moist and warm period is the most favourable to deciduous oak forest. The sequence ends with a Supramediterranean type forest cover. The current Mesomediterranean cover of holm oak coppice was established after the Middle Neolithic, postdating the occupation lifespan of the Abeurador cave. The persistence of the dominant Supramediterranean oak forest is very late compared to other sites in the south of France, which had been transformed under the impact of human activities from as early as the end of the Early Neolithic period (Chabal and Vaschalde, in press). By 6000 years ago, a cooling trend is recorded in climatic proxies (Kaufman et al., 2020), which is not captured by anthracological data either at Abeurador or at other Middle Neolithic sites in southern France (Krauss-Marguet, 1981; Vernet and Thiébault, 1987; Chabal, 1997; Chabal and Vaschalde, in press; among others).

At Abeurador, three main taxa, Pinus type sylvestris, Juniperus and Quercus deciduous, are present through time, except that pine disappears at some point from the sequence. They successively colonized the environs of Abeurador cave, replacing one another, or partially in different biotopes, following the succession of climatic phases, multifactorial shifts in soil conditions, successional dynamics and interspecific competition. As these taxa are in turn dominant, and sometimes co-dominant, it suggests that they were well-adapted overall and have, at different points in time, marked the local landscape. Our goal is to obtain additional information on their degree of spatial dispersion, in order to better describe these dynamics.

\section{Methods and material}

\subsection{Spatial analysis in relation to duration}

Spatial analysis across a layer (and/or a defined context as a phase of occupation) is often used in archaeology for studying artefact distribution (lithics, ceramics) or archaeobiological remains such as bones, seeds and charcoals.

In this study, we were dealing with fuelwood waste debris in habitat contexts. When analysing the spatial dispersion of information, authors generally point out that primary (in situ) or secondary (shifted) concentrated charcoal deposits, i.e. short-term deposits, provide an understanding of one-off fuel use practices through the last firewood used in combustion features, whereas deposits accumulated in the long term are the synthesis of the many uses of wood, averaged over time, permitting palaeoenvironmental interpretation (e.g. Heinz, 1990b; Badal Garcia, 1992; Chabal, 1992; 1997; Théry-Parisot, 2001; Asouti and Austin, 2005; Vidal-Matutano, 2016; Kabukcu, 2018).

The high spatial heterogeneity observed in concentrated charcoals, 
often concretized by highly variable taxon frequencies, is generally studied to try to understand one-off human activities in relation to fire wood use, such as specific wood uses, or more generally fuel management. As they might have been moved, they may or may not follow the functional structuring of the habitat (location of hearths or activities). However, any significant heterogeneity indicates an instantaneous event (fire, activity or deposit) which would be risky to try and interpret as intentional, due to its random nature (Chabal, 1997; Kabukcu and Chabal, this issue). Since human fire-related practices are not the focus of this study, we excluded such short-term deposits from the Abeurador spatial analysis and retained only charcoal scatters accumulated in the long-term.

The aim of spatial analysis in this study was to investigate if any spatial heterogeneity observed in the distribution of scattered charcoals could be linked to the past distribution of taxa in the site environment. This approach differs from previous approaches on the topic of the spatial analysis of fuelwood remains. The residual distribution heterogeneity of scattered charcoals, recorded using a square grid, has a completely different meaning from that of concentrated deposits as it is supposed to refer to long term deposit, originating from multiple dispersal events from one or more hearths, and not from an overall movement of concentrated charcoal from a single fire. An essential practical question is to distinguish between heterogeneity due to the presence of a concentration and residual heterogeneity resulting from the long term dispersion of scattered charcoals. In addition to being very often visible during the excavation, a charcoal concentration generally reveals a significantly different frequency spectrum of taxa (from those of scattered charcoal), that enters the definition of statistical outlier (relative to an average image of the past woodlands). In this study, the record of two hearths and a shifted concentration (excluded from the dataset) illustrates such aberrant frequencies (see section 3.5). Scattered charcoal heterogeneity is always low (see section 4.), if the concentrations have indeed been excluded (which can be done $a$ posteriori, thanks to spatial sampling). At this point, it can already be noted that the frequencies of abundant taxa are fairly evenly distributed in the grid squares and rare taxa are more or less randomly distributed (Heinz, 1990b; Chabal, 1991, 1992, 1997; Badal Garcia, 1992).

\subsection{The working hypothesis}

We address the stochastic processes that may lead to the residual heterogeneity observed in the distribution of charcoal fragments, scattered within a layer. This includes wood collection in a heterogeneous environment, firewood storage, activities involving fire, fire management, combustion, dispersal of residual waste in the living space, trampling, burial, excavation and sieving. We do not have access to most of these successive steps, but we can examine the distortion factors that may affect the frequency spectrum of taxa.

First, the physical processes such as fragmentation, combustion or post-depositional strains appear to have had a regular effect on the species in the long term and maintained their proportions, or slightly and constantly distorted them (Chabal, 1990, 1991, 1992, 1997, 2001; Chabal and Laubenheimer, 1994; Théry-Parisot, 2001; Théry-Parisot et al., 2010a, 2010b; Chrzazvez et al., 2014; Kabukcu and Chabal, this issue).

The information contained in the charcoal scatters of a layer is the addition of multiple events of fuelwood use over a given time span, maybe several months or years, in which most wood has been converted to ash. The dispersal of charcoals in each layer over time, day after day, was certainly centrifugal, from one or more hearths, reaching remote parts of the inhabited space and then accumulating throughout the layer (for a given period). Dispersing factors (e.g. trampling, sweeping) were not related to the location of the various fire-using activities and have probably impacted all taxa in the same way, as does fragmentation (Chabal, 1990; Kabukcu and Chabal, this issue). It would be hazardous to over reason on the dispersing agents and practices that we have no knowledge about. Nevertheless, contrary to the rapid displacement of concentrated charcoal from one or more fires, which led to concentrations and outlier values, it is likely that the charcoal scattering was the result of random dispersions spread over time. This would explain why we find such fairly distributed (within a layer) and above all repeatable (between layers) taxon frequency spectra. The scattering probably followed daily fire-related activities in the form of partial or total exports of hearth content, followed by further dispersions unrelated to the fire, finally recording a residual heterogeneity in the spatial distribution of taxa frequencies, depending on the wood content of the successive fires.

Our working hypothesis is that the probability of a species having been regularly or irregularly collected in the environment, during repeated firewood collection events, may have led to heterogeneous hearth inputs, which in turn led to heterogeneous dispersal episodes of hearth fuel waste in the archaeological layer. It is quite conceivable that the probability of a species being present in a single fuelwood collection event depends on the distribution of that species in the environment. A wood species that is uniformly distributed in woodland vegetation will appear regularly in many wood collection events and, more rarely, will be absent or dominant in firewood harvests. Conversely, species characterized by highly localized distributions or limited accessibility may be underrepresented in most of the fuelwood collection harvests (regardless of local abundance) and overrepresented in a few.

However, another hypothesis must be examined. Could the heterogeneity of wood use, due to particular preferences or activities, have led to the heterogeneous hearth inputs registered? This hypothesis does not seem the most suitable, as (i) debates on the selection of species for fuel
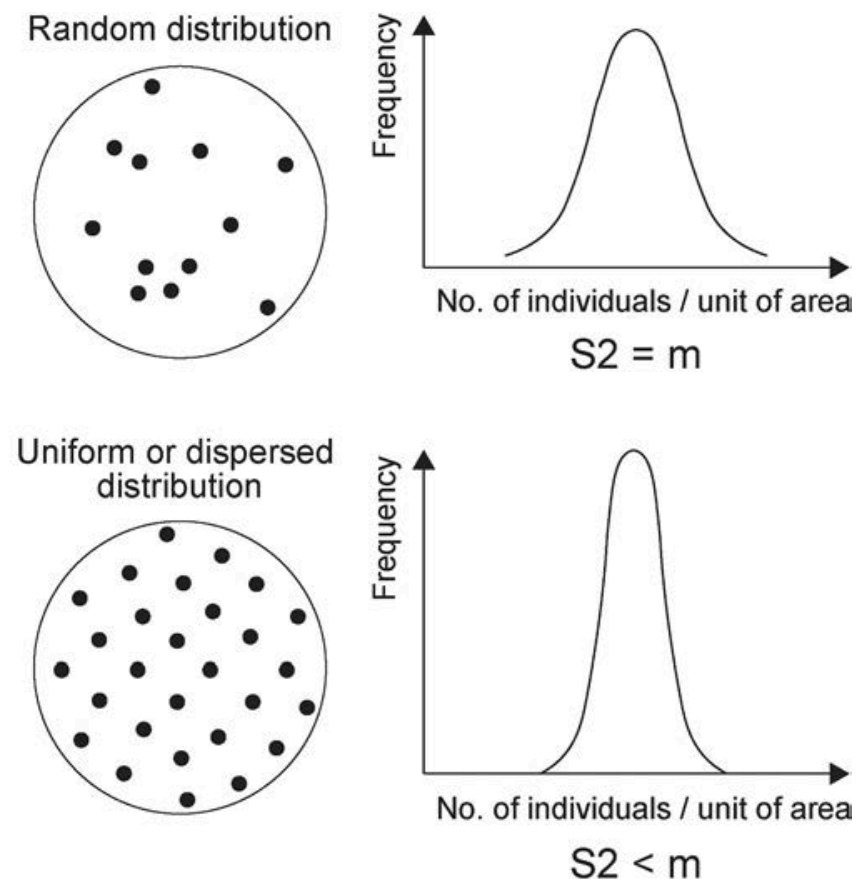

Clumped or aggregated
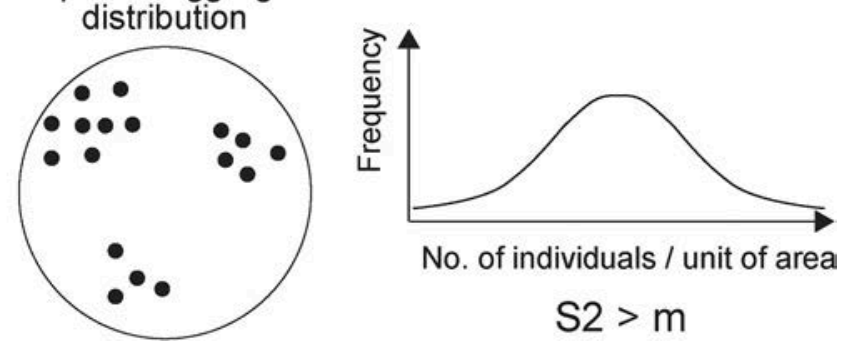

Fig. 4. Three theoretical types of distribution of living organisms in their natural environment: (a) random, (b) uniform and (c) clumped. 
use, in light of wood properties and ethnographic studies, led to the conclusion that preferences for certain taxa to perform specific tasks are cultural or individual habits rather than objective species suitability (Chabal, 1997; Théry-Parisot, 2001; Henry, 2011; Kabukcu and Chabal, this issue), (ii) several wood uses certainly followed one another within a single day (e.g. lighting the fire, cooking, heating, lighting the cave, smoking meat, working with various materials, etc.), leading to a mixture of different successive choices and (iii) all the taxa collected and stored were probably used within a short duration, as no taxon was rejected for fire.

If an active selection of taxa did occur for any purpose, this is likely to have been during collection. It is generally acknowledged that an overrepresentation of rare taxa in fuelwood could only have lasted for a limited time before their disappearance and that the major taxa provided most of the fuelwood (Chabal, 1997). Some of the major taxa may have been slightly over- or under-represented relative to their abundance in the environment, due to particular behaviours, availability of dead wood according to taxa, or vegetation physiognomy, although this remains under-theorized. However, the potential distortion of the proportions between species were (i) regular, since they depend on regular factors as cultural habits or biological features and (ii) small, since the anthracological frequency spectrum is consistent with current forest compositions and coherent with observed forest dynamics.

Another key point is the temporality of the successive events that may have distorted the frequencies of the taxa with respect to their average frequency in the collection area. It is likely that variations in wood use (if there were any) were more frequent (e.g. several of them within a single day) than variations in wood collection (at most once a day, perhaps much less, and even rarer for more distant incursions). Consequently, the heterogeneity of wood inputs throughout successive collections is more likely to have contributed to that of the dispersed residues than successive uses.

Due to its probability of collection, the proportion of a taxon fluctuated in firewood assemblages, and then in residual charcoal in squares of the excavated site, relative to its heterogeneity of distribution (or accessibility) in the site environs during human occupation. Our working hypothesis states that the fuelwood waste regularly disposed of and entering the archaeological record in the form of charcoal scatters retained the residues of this spatial heterogeneity, which likely characterized successive firewood collection events. We thus hypothesize that the frequency distribution of each taxon in a layer (per grid square) may represent its sampling distribution (i.e. the probability distribution of a statistic based on a random sample) in the past environment.

\subsection{The distribution index as an indicator of vegetation heterogeneity}

In order to study the vegetation heterogeneity across the distribution of charcoals, we referred to distributional patterns used in ecological studies. According to Molles and Sher (2019), at a small scale (i.e. small distances over which there is little environmental change significant to the organism under study), individuals within populations are distributed in patterns that may be random, regular, or clumped. Individuals are sampled in sample plots to estimate the mean (m) and variance (s2) in density of the population across the study area. The ratio $\mathrm{s} 2 / \mathrm{m}$ (variance/mean), named the 'distribution index', estimates the regularity of the distribution of individuals in the population across the study area (Fig. 4).

(a) A random distribution ( $\mathrm{s} 2 / \mathrm{m}=1$ or $\mathrm{s} 2=\mathrm{m}$ ) of individuals is the least common form of distribution in nature, occurring only when the position of each individual of the species is independent of the other individuals. Individuals have an equal chance of living anywhere within an area. This distribution would imply neutral interactions between individuals, and between individuals and the local environment. On the contrary, in most environments, interactions with neighbouring individuals and other factors, such as climate or soil conditions, generally cause organisms to be either clustered or dispersed.

(b) A uniform or dispersed distribution (s $2 / \mathrm{m}<1$ or $\mathrm{s} 2<\mathrm{m}$ ) implies that individuals occupy the land approximately at the same distance from each other. This distribution supposes antagonistic interactions between individuals, or local depletion of resources. The need to maximize the space between individuals arises from competition for a resource (e.g. moisture or light), or as a result of direct interactions between individuals within the population, such as root interactions. This can be seen in the regularity of spacing among bushes in arid zones (when the density of the individuals is sufficient for the phenomenon to appear).

(c) A clumped, aggregative or clustered distribution (s2/m $>1$ or $\mathrm{s} 2>\mathrm{m}$ ) is characterized by a tendency for individuals to group together. It is the most common type of dispersion found in nature. It involves a beneficial attraction between individuals or an attraction of individuals to a common resource (e.g. water, soil, temperature, shade). This type of distribution is found in environments characterized by unequal resources. For plants, it corresponds to populations with biotope preferences and local spreading.

For our purpose, we used the distribution index to estimate the regularity of the distribution of percentage of each taxon in the grid squares. As $\mathrm{s} 2$ and $\mathrm{m}$ (in the sample) are supposed to estimate $\sigma 2$ and $\mu$ (in the past environment), we attempted to use them to estimate the heterogeneity of past vegetation, at least to compare population density patterns of major taxa. In order to use the mean and variance of the frequency distributions of taxa, it was necessary to verify beforehand whether taxa frequencies were distributed in the layers according to the normal law. Finally, distribution indexes were calculated for the most represented taxa, in the two layers studied, in order to understand their past location in the surroundings of the Abeurador during the Mesolithic, in the context of the whole postglacial vegetation evolution.

\subsection{The size of the fuelwood supply area}

The size of the firewood supply area, which charcoal can represent, depends on energy requirements and forest wood productivity. According to current rural areas, domestic energy needs are estimated to vary, from low-lying tropical regions to cold mountainous areas, between 0.5 and $2 \mathrm{~m} 3$ /person/yr of dry wood (Rey and Hermeline, 1994). For the Mesolithic, under a cold/mild climate, we have considered the highest estimate of $2 \mathrm{~m} 3$ /person/yr, which maximizes the supply area. Regarding forest productivity, pine forests regenerated by seed or woodlands regenerated by coppice resprouting have a relatively low productivity per hectare but a high capacity for regrowth after cutting, which lasts over time. According to Jolain (1961) current Mediterranean oak coppice produces $0.6-3 \mathrm{~m}^{3} / \mathrm{ha} / \mathrm{yr}$. A yield of $2 \mathrm{~m}^{3} / \mathrm{ha} / \mathrm{yr}$ is retained by Curt and Marsteau (1997) and Jamet (2001). During the Mesolithic period, it can be assumed that pine forests, open steppe-forests or young spreading oak forests, had a productivity of at least $2 \mathrm{~m} 3 / \mathrm{ha} / \mathrm{yr}$. According to these data, a community of 40 people, consuming $80 \mathrm{~m} 3$ of firewood per year, would satisfy these needs from a mainly forested area of 40 ha. More generally, according to extant models of woodland use, the fuelwood (and possibly farmland) needs of a modestly-sized hunter-gatherer or agro-pastoralist community can be met within a radius of a few hundred metres, though this varies according to group size, the density of woodland cover and the range of human activities in the landscape (Chabal, 1997; Bourquin-Mignot et al., 1999; Théry-Parisot, 2001).

In this study, modelling past woodland vegetation through the lens of fuelwood supply and availability, we considered the wider partly forested area $1 \mathrm{~km}$ radius around the cave, i.e. 314 ha. Assuming the lowest productivity of $2 \mathrm{~m} 3 / \mathrm{ha}$ /year, this woodland area would produce 
Table 2

Number of charcoals per taxon and per square in Layer C6 of the Abeurador cave. Hearths were excluded from the study (after Heinz, 1990a).

\begin{tabular}{|c|c|c|c|c|c|c|c|c|c|c|c|c|c|c|c|}
\hline Taxon & $\begin{array}{l}\text { Abbreviated } \\
\text { name of taxa }\end{array}$ & H10 & H9 & H8 & H7 & G10 & G9 & G8 & G7 & F9 & E10 & F8 & $\begin{array}{l}\text { Total per taxon } \\
\text { (excluding } \\
\text { hearths) }\end{array}$ & $\begin{array}{l}\text { Hearth } \\
\text { in } H 9\end{array}$ & $\begin{array}{l}\text { Hearth in } \\
\text { F8-G8 }\end{array}$ \\
\hline Pinus type sylvestris & P.s. & 17 & 22 & 42 & 14 & 13 & 16 & 10 & 17 & 5 & 4 & 1 & 161 & 16 & 5 \\
\hline Juniperus & Ju. & 132 & 115 & 93 & 44 & 118 & 111 & 78 & 45 & 54 & 52 & 31 & 873 & 200 & 25 \\
\hline Quercus deciduous & Q.d. & 28 & 9 & 30 & 7 & 22 & 21 & 24 & 11 & 38 & 4 & 19 & 213 & 16 & 100 \\
\hline Acer campestre & A.c. & 46 & 22 & 21 & 12 & 17 & 17 & 27 & 7 & 22 & 30 & 6 & 227 & 11 & 0 \\
\hline Acer monspessulanum & A.m. & 8 & 4 & 8 & 2 & 2 & 4 & 4 & 2 & 8 & 3 & 2 & 47 & 0 & 0 \\
\hline Corylus avellana & C.a. & 1 & 0 & 2 & 2 & 0 & 0 & 2 & 0 & 0 & 0 & 2 & 9 & 0 & 13 \\
\hline $\begin{array}{l}\text { Total Prunoideae } \\
\text { (including Prunus } \\
\text { spinosa, Prunus mahaleb) }\end{array}$ & Pru. & 28 & 19 & 3 & 15 & 28 & 17 & 42 & 14 & 22 & 6 & 22 & 216 & 0 & 105 \\
\hline $\begin{array}{l}\text { Total Maloideae } \\
\qquad \text { (Crataegus }+ \text { Sorbus })\end{array}$ & Mal. & 0 & 2 & 6 & 3 & 5 & 1 & 1 & 5 & 8 & 2 & 2 & 35 & 0 & 0 \\
\hline Quercus type ilex & Q.i. & 0 & 0 & 0 & 0 & 1 & 0 & 2 & 0 & 1 & 0 & 2 & 6 & 0 & 0 \\
\hline $\begin{array}{l}\text { Phillyrea/Rhamnus } \\
\text { alaternus }\end{array}$ & Ph.Rh. & 0 & 0 & 1 & 1 & 0 & 0 & 2 & 1 & 3 & 0 & 2 & 10 & 0 & 0 \\
\hline Buxus sempervirens & B.s. & 0 & 0 & 0 & 0 & 2 & 0 & 0 & 0 & 2 & 0 & 1 & 5 & 0 & 0 \\
\hline Lonicea & Lo. & 0 & 1 & 0 & 0 & 0 & 0 & 0 & 0 & 0 & 0 & 0 & 1 & 0 & 0 \\
\hline Pistacia terebinthus & P.t. & 2 & 0 & 0 & 0 & 0 & 1 & 1 & 0 & 0 & 0 & 0 & 4 & 0 & 0 \\
\hline Sambucus & Sa. & 0 & 2 & 0 & 0 & 0 & 0 & 0 & 0 & 0 & 0 & 0 & 2 & 0 & 0 \\
\hline Taxus baccata & T.b. & 1 & 0 & 0 & 0 & 2 & 0 & 1 & 0 & 0 & 0 & 0 & 4 & 0 & 0 \\
\hline Tilia & Ti. & 0 & 0 & 0 & 0 & 0 & 0 & 1 & 0 & 0 & 0 & 1 & 2 & 0 & 0 \\
\hline Ulmus minor & U.m. & 0 & 0 & 0 & 0 & 0 & 1 & 0 & 0 & 0 & 0 & 0 & 1 & 0 & 0 \\
\hline Viburnum lantana & V.1. & 0 & 0 & 0 & 0 & 0 & 1 & 0 & 0 & 0 & 0 & 0 & 1 & 5 & 0 \\
\hline Vitis vinifera & V.v. & 0 & 0 & 0 & 0 & 0 & 0 & 0 & 0 & 0 & 0 & 1 & 1 & 0 & 0 \\
\hline $\begin{array}{l}\text { Number of charcoals per } \\
\text { square }\end{array}$ & & 266 & 196 & 206 & 100 & 210 & 190 & 195 & 102 & 163 & 101 & 92 & 1821 & 250 & 250 \\
\hline
\end{tabular}

Table 3

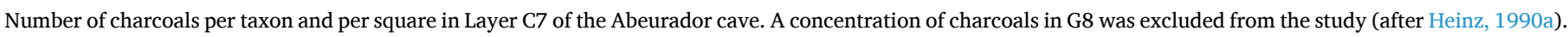

\begin{tabular}{|c|c|c|c|c|c|c|c|c|c|c|c|c|c|c|c|}
\hline Taxon & $\begin{array}{l}\text { Abbreviated } \\
\text { name of taxa }\end{array}$ & $\mathrm{H} 10$ & H9 & H8 & $\mathrm{H} 7$ & G10 & G7 & F10 & F9 & F8 & F6 & E9 & E6 & $\begin{array}{l}\text { Total per taxon } \\
\text { (excluding G8) }\end{array}$ & $\begin{array}{l}\text { Concentration } \\
\text { in } G 8\end{array}$ \\
\hline Pinus type sylvestris & P.s. & 48 & 122 & 78 & 52 & 28 & 47 & 45 & 50 & 23 & 52 & 21 & 26 & 644 & 52 \\
\hline Juniperus & Ju. & 61 & 169 & 54 & 45 & 62 & 25 & 79 & 61 & 30 & 43 & 60 & 14 & 711 & 8 \\
\hline Quercus deciduous & Q.d. & 4 & 39 & 11 & 5 & 5 & 10 & 7 & 11 & 14 & 15 & 18 & 14 & 154 & 1 \\
\hline Acer campestre & A.c. & 18 & 35 & 19 & 18 & 19 & 13 & 27 & 32 & 8 & 18 & 36 & 14 & 258 & 1 \\
\hline Acer monspessulanum & A.m. & 2 & 0 & 1 & 1 & 4 & 4 & 1 & 4 & 0 & 2 & 2 & 1 & 25 & 3 \\
\hline Corylus avellana & C.a. & 0 & 2 & 0 & 0 & 0 & 0 & 0 & 1 & 1 & 3 & 4 & 1 & 12 & 0 \\
\hline $\begin{array}{l}\text { Total Prunoideae } \\
\text { (including Prunus } \\
\text { spinosa, Prunus mahaleb) }\end{array}$ & Pru. & 9 & 48 & 29 & 29 & 19 & 16 & 28 & 22 & 12 & 8 & 32 & 13 & 291 & 26 \\
\hline $\begin{array}{l}\text { Total Maloideae } \\
\quad(\text { Crataegus }+ \text { Sorbus })\end{array}$ & Mal. & 8 & 12 & 1 & 5 & 3 & 2 & 2 & 6 & 7 & 8 & 5 & 6 & 65 & 0 \\
\hline Quercus type ilex & Q.i. & 0 & 0 & 0 & 0 & 1 & 0 & 0 & 0 & 0 & 0 & 0 & 0 & 1 & 0 \\
\hline $\begin{array}{l}\text { Phillyrea/Rhamnus } \\
\text { alaternus }\end{array}$ & Ph.Rh. & 0 & 0 & 2 & 0 & 1 & 0 & 2 & 5 & 0 & 0 & 0 & 2 & 13 & 1 \\
\hline Buxus sempervirens & B.s. & 0 & 0 & 0 & 0 & 0 & 0 & 0 & 1 & 0 & 0 & 4 & 0 & 5 & 0 \\
\hline Pistacia terebinthus & P.t. & 0 & 3 & 0 & 0 & 0 & 0 & 0 & 0 & 0 & 0 & 0 & 0 & 3 & 0 \\
\hline Sambucus & Sa. & 0 & 4 & 0 & 0 & 0 & 0 & 0 & 0 & 0 & 0 & 0 & 0 & 4 & 0 \\
\hline Taxus baccata & T.b. & 0 & 0 & 0 & 0 & 0 & 0 & 0 & 0 & 1 & 0 & 0 & 0 & 1 & 0 \\
\hline Ulmus minor & U.m. & 0 & 0 & 0 & 0 & 0 & 0 & 0 & 1 & 0 & 0 & 2 & 0 & 3 & 0 \\
\hline Viburnum lantana & V.l. & 0 & 0 & 0 & 0 & 0 & 0 & 0 & 1 & 1 & 0 & 0 & 0 & 2 & 0 \\
\hline Ilex aquifolium & I.a. & 0 & 1 & 0 & 0 & 0 & 0 & 0 & 0 & 0 & 0 & 0 & 0 & 1 & 0 \\
\hline $\begin{array}{l}\text { Number of charcoals per } \\
\text { square }\end{array}$ & & 150 & 435 & 195 & 155 & 142 & 117 & 192 & 195 & 98 & 149 & 184 & 91 & 2103 & 92 \\
\hline
\end{tabular}

$628 \mathrm{~m} 3$ of fuelwood per annum without exhausting its potential, which far exceeds the needs of a community numbering a few dozen people, apart from the fact that occupation was seasonal. In the case of Abeurador, occasional inputs (hunting, fishing) from further away have been assumed (Vaquer and Ruas, 2009), although the expectation is that distant procurement did not involve fuelwood collection. The taxon composition, as evidenced in the anthracological spectra, is highly consistent with the hilly surroundings and, conversely, includes few alluvial indicator taxa. The plain was certainly not the setting for regular wood harvesting.

\subsection{Studied material at Abeurador cave}

In the 1990s, charcoals were sampled at Abeurador cave using a $1 \times$ $1 \mathrm{~m}$ excavation grid. Palaeoecological interpretation was based on the taxonomic frequency spectra obtained from the sum of the contents of the squares in each layer; the square distribution was then used to check the reliability of the dataset (Heinz, 1990a; Heinz et al., 1992; Heinz and Thiébault 1998). The hearth contents were sampled and studied separately (Heinz, 1990a, 1990b). In this study, we focused on the distribution of the per square taxon frequency spectra in two successive Early/Middle Mesolithic layers, corresponding to a phase of changing vegetation dynamics during the Early Holocene (Preboreal). Layer C6 totals 1821 charcoal fragments and Layer C7 2103 fragments. These two 

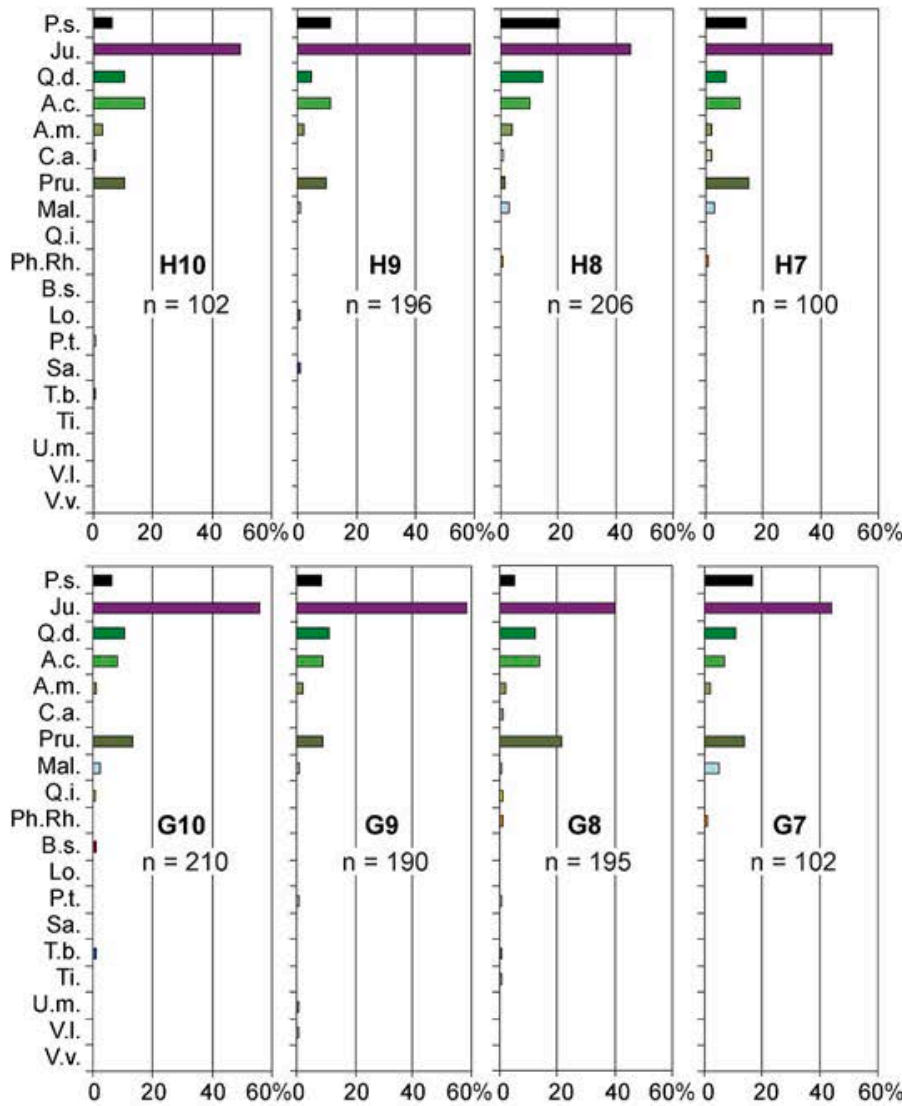

\section{C6 layer squares}
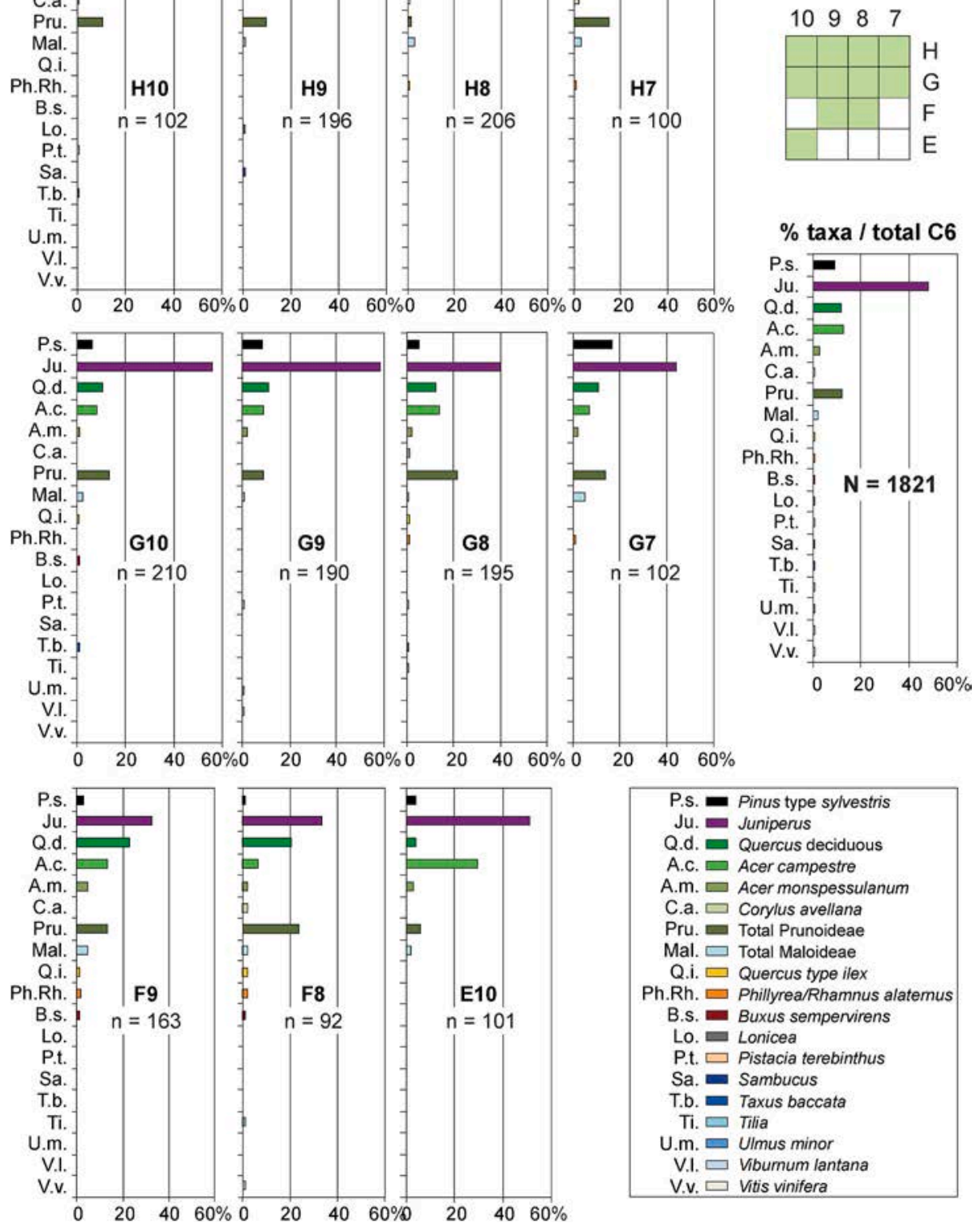

Fig. 5. Bar graphs of the relative frequency spectra of taxa per square in Layer C6.

layers were the richest on the site and the only ones that yielded a high number of charcoals per square $(n=100-400)$, permitting the application of statistical analysis using the distribution index. Two hearths in Layer C6 (Table 2) and a concentration in the square G8 of Layer C7 (Table 3), in which some taxa were clearly over-represented compared to the average spectrum, were excluded from the dataset.

\section{Results}

Per square taxon frequency spectra were recorded for 11 grid squares from Layer C6 and 12 from Layer C7. The absolute taxon frequencies are presented in Tables 2 and 3 and bar graphs of the relative frequency spectra of taxa per square have been plotted (Figs. 5 and 6).

At first sight, in both Layers C6 and C7, the frequency distribution of major taxa appears fairly uniform between squares. However, the relative frequencies of the most common taxa are not uniformly distributed in the squares. Global $\chi^{2}$ tests on absolute frequencies show that the square contents (taxon frequencies) are significantly different within each layer. The taxa tested were Pinus tp. sylvestris, Juniperus, Quercus deciduous, Acer campestre, total Prunoideae, and 'other taxa' (taxa with a frequency of $<5$ were pooled together).

Layer C6: $\chi^{2}=250$, dof $=50, p<0.0001$

Layer C7: $\chi^{2}=182$, dof $=55, \mathrm{p}<0.0001$

In Layer C6, the taxa which contributed most to these differences were Pinus tp. sylvestris (26\%), Quercus deciduous (20\%) and Juniperus (18\%). The square mainly involved in these differences was E9 (18\%). In Layer C7, the species which contributed the most to these differences were Pinus tp. sylvestris (25\%), Prunoideae (21\%) and Quercus deciduous (17\%). The square which contributed most to these differences was H8 (21\%). These variations are not surprising as the $\chi^{2}$ test often exaggerates differences.

According to the Shapiro-Wilk tests, the hypothesis that the relative 

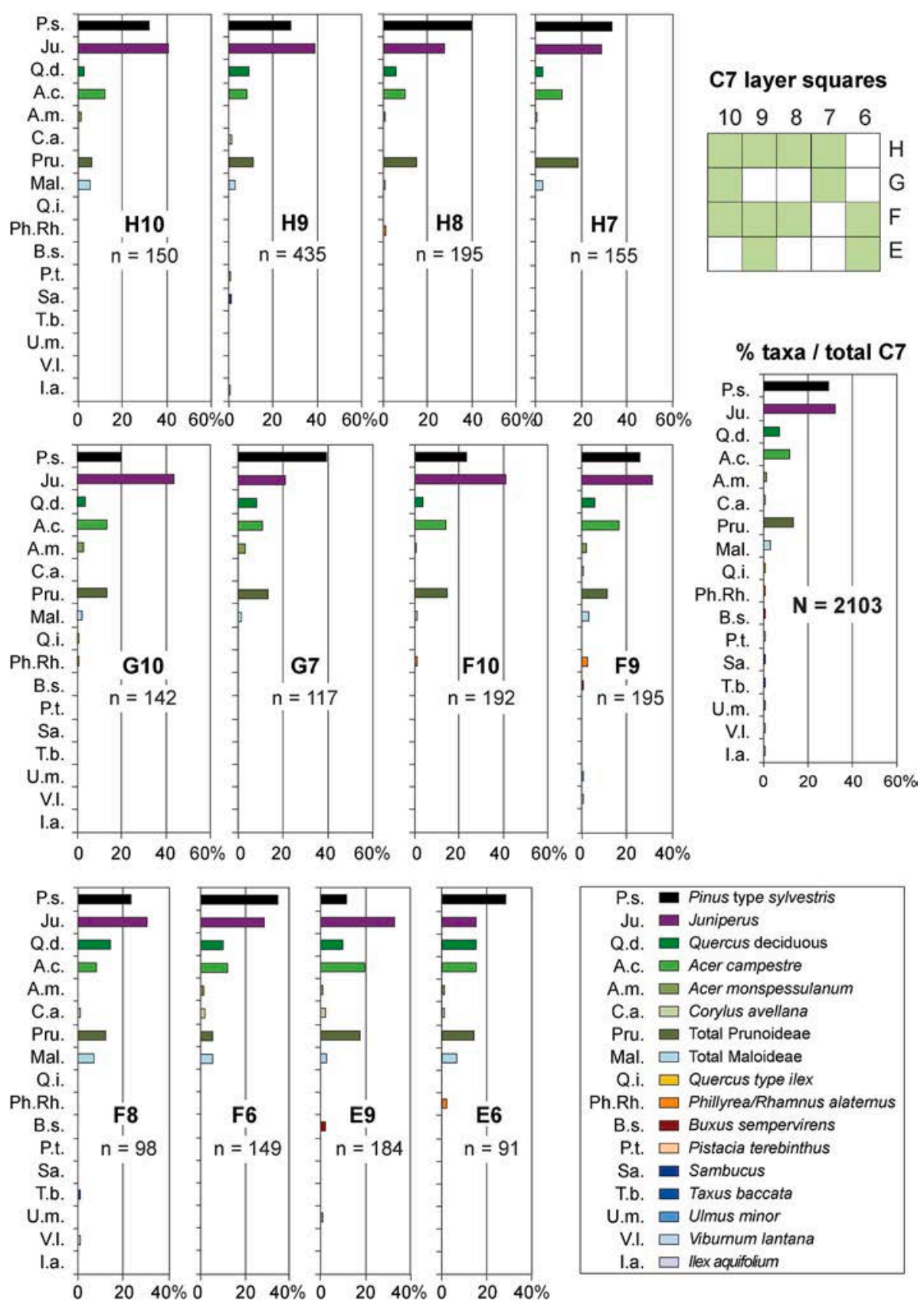

Fig. 6. Bar graphs of the relative frequency spectra of taxa per square in Layer C7.

frequencies of a taxon are normally distributed in the grid squares cannot be rejected for seven abundant taxa (Table 4). For other taxa, mixture analyses were done to exclude multimodal distributions, ruling out the hypothesis of two or several populations of data (e.g. two or several species in one genus, with different frequencies). Poorly represented taxa have a distribution that does not follow the normal law due to their low numbers. Normality was also rejected for Acer campestre in Layer C6, despite its rather large count, because it is overrepresented in the E10 square. If we correct the data by removing the A. campestre frequency in the E10 square (which does not change its total relative frequency much) normality is no longer rejected, making it possible to calculate a distribution index. However, this distribution index was not retained by the goodness-of-fit test (see below).

The fact that the seven most abundant taxa are distributed in the squares according to the normal law (with minor adjustments) confirms the huge statistical interest of the charcoal deposits and allows us to obtain representative results from sampling a few squares (possible because the standard deviation is not too high compared to the mean). Furthermore, in accordance with our initial hypothesis, the frequency distribution of a taxon in a layer can be considered to represent its statistical sampling distribution (i.e. probability distribution) in the wood collection catchment.

The distribution averages are different from one taxon to another, since their mean frequencies in each layer are different. The distribution variances also differ, which is what we focus on here (Fig. 7). The distribution index s $2 / \mathrm{m}$ (variance/mean), which estimates the regularity of the taxon distribution in the grid squares, has therefore been calculated for the seven abundant taxa (Table 5). The considered mean (called $\mathrm{m}$ ) of the relative frequencies per square of a taxon is the average of its independent relative frequencies in the squares of the layer, regardless of the total number of charcoals in each square. This mean is very close to the mean of the taxon (called \%, Table 4) calculated from the total 
Table 4

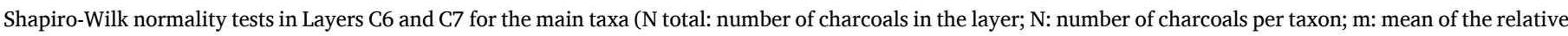
frequencies per square; \%: N/N total x 100).

\begin{tabular}{|c|c|c|c|c|c|c|c|c|c|c|}
\hline & \multicolumn{5}{|c|}{ Layer C7 } & \multicolumn{5}{|c|}{ Layer C6 } \\
\hline & \multicolumn{5}{|c|}{$\mathrm{N}$ total $=2103$} & \multicolumn{5}{|c|}{$\mathrm{N}$ total $=1821$} \\
\hline & $\mathrm{N}$ & $\%$ & $\mathrm{~m}$ & $\begin{array}{l}\text { Shapiro-Wilk test p- } \\
\text { value }\end{array}$ & $\begin{array}{l}\text { Normality (alpha }= \\
0.05)\end{array}$ & $\mathrm{N}$ & $\%$ & $\mathrm{~m}$ & $\begin{array}{l}\text { Shapiro-Wilk test p- } \\
\text { value }\end{array}$ & $\begin{array}{l}\text { Normality (alpha }= \\
0.05)\end{array}$ \\
\hline Pinus type sylvestris & 592 & 28.2 & 28.4 & 0.8745 & + & 161 & 8.8 & 8.8 & 0.4428 & + \\
\hline Juniperus & 703 & 33.4 & 31.8 & 0.6258 & + & 873 & 47.9 & 46.8 & 0.4553 & + \\
\hline Quercus deciduous & 153 & 7.3 & 7.6 & 0.1940 & + & 213 & 11.7 & 11.8 & 0.2872 & + \\
\hline $\begin{array}{l}\text { Acer campestre (without E10 } \\
\text { for C6) }\end{array}$ & 257 & 12.2 & 12.6 & 0.8091 & + & 227 & 10.8 & 10.8 & 0.7865 & + \\
\hline Acer monspessulanum & 25 & 1.0 & 1.2 & 0.2140 & + & 47 & 2.6 & 2.6 & 0.0995 & + \\
\hline Total Prunoideae & 265 & 12.6 & 12.7 & 0.3738 & + & 216 & 11.9 & 12.5 & 0.8260 & + \\
\hline Total Maloideae & 65 & 0.6 & 3.5 & 0.3922 & + & 35 & 1.9 & 2.2 & 0.3378 & + \\
\hline Corylus avellana & 12 & 3.1 & & 0.0047 & - & 9 & 0.5 & & 0.0078 & - \\
\hline Phillyrea + Rhamnus alaternus & 12 & 0.6 & & 0.0017 & - & 10 & 0.5 & & 0.0215 & - \\
\hline
\end{tabular}

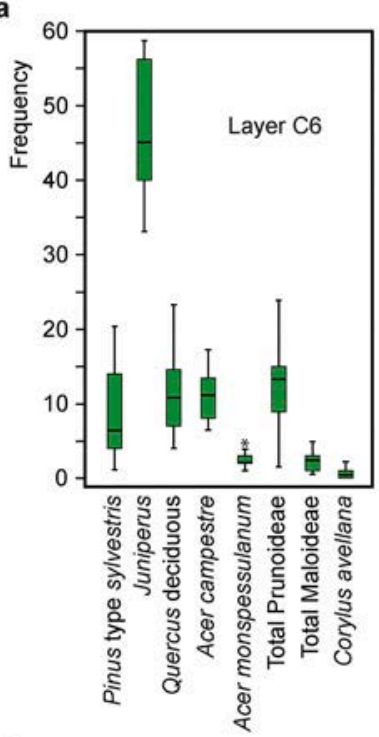

b

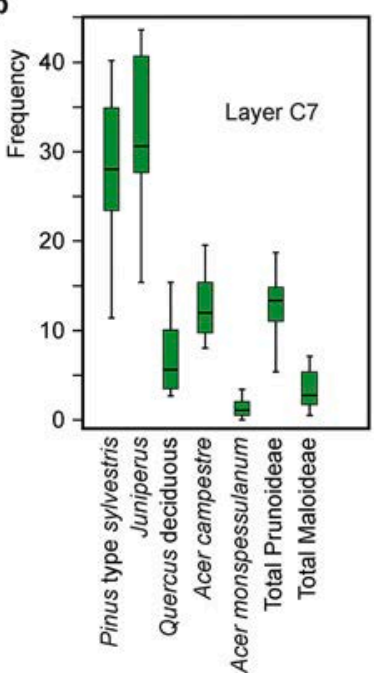

range from 0.45 to 4.22 .

The value of $\mathrm{s} 2 / \mathrm{m}$ represents an estimate, derived from a limited number of squares, of the theoretical value that would have been obtained for an infinite number of squares in a given archaeological layer. In order to test the significance of our results, our null hypothesis HO would be that the distribution of the frequencies of a taxon in the squares would not differ from a random distribution. In section 3.3., we mentioned that in a random distribution, the distribution index value equals $1(\mathrm{~s} 2 / \mathrm{m}=1)$. Our alternative hypothesis proposes that taxon frequencies are either clumped or uniformly distributed. We used a $\chi 2$ goodness-of-fit test to determine how well the observed frequency distribution matches the expected frequency distribution (random distribution), i.e. whether the sample variance/sample mean ratio is significantly different from 1 . The $\chi 2$ values show that the main taxa Pinus type sylvestris, Juniperus and Quercus deciduous, and also Prunoideae in C6 level, have distributions that differ significantly from a random distribution (Table 5). We thus reject the null hypothesis HO. As their distribution indexes are $>1$, they are characterized by clumped distributions, with variations in the degree of aggregation of individuals.

\section{Discussion}

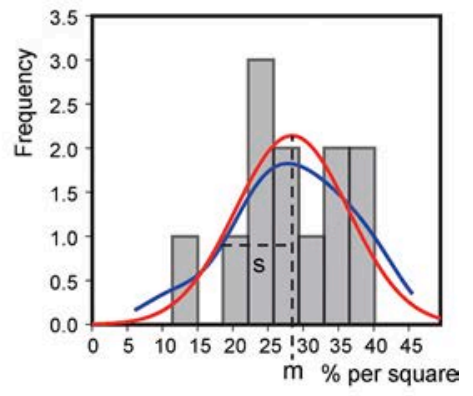

Frequency distribution of Pinus type sylvestris $(n=592)$ in Layer C7 normal distribution Kernel density

Fig. 7. On the left, box plots of the relative frequencies per square of the main taxa. On the right, a distribution histogram as an example. (a) Layer C6 and (b) Layer C7 (m: mean; s: standard deviation; the star indicates an outlier). Each taxon frequencies are normally distributed in the grid squares, although they are relatively dispersed.

number of charcoals of the taxon in the layer. The distribution indexes

\subsection{Distribution indexes signification at a micro-regional scale}

In this study, we assumed that taxon proportions fluctuated in each assemblage of firewood due to its probability of collection, relative to its distribution heterogeneity (or accessibility) in the environment. The distribution indexes values (Table 5), statistically validated for four major taxa in the C6 and C7 layers of the Abeurador, are supposed to represent their distribution patterns at a small scale, that of the cave surroundings during the Mesolithic. Can the distribution patterns of the main species in Layers C7 and C6 help us to better understand the dynamic successions of the woodlands around the Abeurador cave for the whole sequence?

The Abeurador environment was considered at a micro-regional scale, as the fuelwood was collected within a radius of less than $1 \mathrm{~km}$ (see section 3.4). The distribution indexes range from 1.75 for Juniperus in Layer C6 to 4.4 for Pinus type sylvestris in Layer C6. The validated indexes are greater than 1 , indicating clumped distributions. This corresponds well to a micro-regional ecological structure made of several forest types. It is likely that species distribution in a fairly heterogeneous environment with a rugged topography leads to all dominant taxa having clumped distributions of individuals. On a finer scale, more uniform distributions might have been observed. Nevertheless, we can use these values to interpret the more or less clumped patterns according to taxa and compare their variations over time. 
Table 5

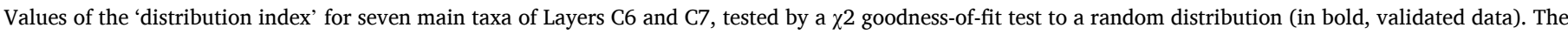

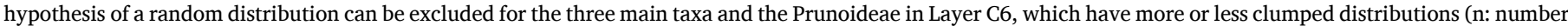

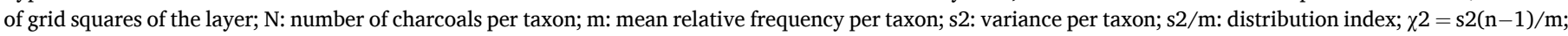
significance level $\mathrm{p} \leq 0.05$ ).

\begin{tabular}{|c|c|c|c|c|c|c|c|c|c|c|c|c|}
\hline & \multicolumn{6}{|c|}{ Layer C7 ( $\mathrm{n}=12)$} & \multicolumn{6}{|c|}{ Layer C6 $(\mathrm{n}=11)$} \\
\hline & $\mathrm{N}$ & $\mathrm{m}$ & s2 & $\begin{array}{l}\mathrm{s} 2 / \\
\mathrm{m}\end{array}$ & $\begin{array}{l}\chi 2 / \text { random } \\
\text { distribution }\end{array}$ & $\begin{array}{l}\mathrm{p} \leq \\
0.05\end{array}$ & $\mathrm{~N}$ & $\mathrm{~m}$ & s2 & $\begin{array}{l}\mathrm{s} 2 / \\
\mathrm{m}\end{array}$ & $\begin{array}{l}\chi 2 / \text { random } \\
\text { distribution }\end{array}$ & $\begin{array}{l}\mathrm{p} \leq \\
0.05\end{array}$ \\
\hline Pinus type sylvestris & 592 & 28.4 & 70.50 & 2.48 & 27.3 & + & 161 & 8.8 & 37.10 & 4.22 & 42.2 & + \\
\hline Juniperus & 703 & 31.8 & 70.04 & 2.2 & 24.3 & + & 873 & 46.8 & 81.80 & 1.75 & 17.5 & + \\
\hline Quercus deciduous & 153 & 7.6 & 18.39 & 2.41 & 26.6 & + & 213 & 11.8 & 36.01 & 3.06 & 30.6 & + \\
\hline $\begin{array}{l}\text { Acer campestre (without E10 for } \\
\text { C6) }\end{array}$ & 257 & 12.6 & 11.45 & 0.91 & 10.0 & - & 197 & 10.8 & 11.68 & 1.08 & 10.8 & - \\
\hline Acer monspessulanum & 25 & 1.2 & 1.13 & 0.92 & 10.1 & - & 47 & 2.6 & 1.16 & 0.45 & 4.5 & - \\
\hline Total Prunoideae & 265 & 12.7 & 15.81 & 1.24 & 13.7 & - & 216 & 12.5 & 40.96 & 3.28 & 32.8 & + \\
\hline Total Maloideae & 65 & 3.5 & 4.65 & 1.34 & 14.8 & - & 35 & 2.2 & 2.78 & 1.26 & 12.6 & - \\
\hline
\end{tabular}

Table 6

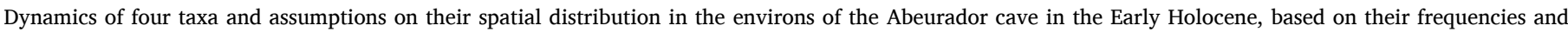
distribution indexes in Layers C7 and C6.

\begin{tabular}{|c|c|c|c|c|c|c|}
\hline Taxon & Layer & $\%$ & $\begin{array}{l}\text { Abundance and dynamic trend (global } \\
\text { warming, competition and soil } \\
\text { conditions) }\end{array}$ & $\begin{array}{l}\text { Distr. } \\
\text { index }\end{array}$ & Distribution pattern & Spatial distribution in the cave environs \\
\hline \multirow[t]{2}{*}{ Pinus type sylvestris } & C6 & 9 & In strong decline & 4.22 & Highly clumped & $\begin{array}{l}\text { The pine area contracts strongly, in the ravines and at } \\
\text { fairly high altitude }\end{array}$ \\
\hline & C7 & 30 & Quite abundant but in decline & 2.48 & Clumped & $\begin{array}{l}\text { Still adapted and widespread, except on dry and poor } \\
\text { soil }\end{array}$ \\
\hline \multirow[t]{2}{*}{ Quercus deciduous } & $\mathrm{C} 6$ & 12 & $\begin{array}{l}\text { Spreading further in open space, } \\
\text { seedlings need shade to grow }\end{array}$ & 3.06 & Very clumped & $\begin{array}{l}\text { Oak expands on the plateau system as localized } \\
\text { clusters, dependent on the protective cover of } \\
\text { Prunoideae and junipers }\end{array}$ \\
\hline & C7 & 7 & $\begin{array}{l}\text { More or less scarse, starting to spread, } \\
\text { favoured by warming }\end{array}$ & 2.41 & Clumped & $\begin{array}{l}\text { Located on the south-facing slopes inherited from the } \\
\text { Younger Dryas; rather clumped }\end{array}$ \\
\hline \multirow{2}{*}{$\begin{array}{l}\text { Prunoideae } \\
\text { (including Prunus } \\
\text { spinosa) }\end{array}$} & $\mathrm{C} 6$ & 12 & $\begin{array}{l}\text { Constant (associated with oak groves), } \\
\text { favoured by warming, heliophilic }\end{array}$ & 3.28 & $\begin{array}{l}\text { Very clumped (as } \\
\text { Quercus deciduous) }\end{array}$ & $\begin{array}{l}\text { Bushes or trees precede and protect the expansion of } \\
\text { oaks, in the form of clusters }\end{array}$ \\
\hline & $\mathrm{C} 7$ & 13 & & - & - & - \\
\hline \multirow[t]{2}{*}{ Juniperus spp. } & $\mathrm{C} 6$ & 48 & $\begin{array}{l}\text { Spreading further into the newly opened } \\
\text { spaces left by pine }\end{array}$ & 1.75 & $\begin{array}{l}\text { Sparsely clumped or } \\
\text { unclumped }\end{array}$ & $\begin{array}{l}\text { Spreads almost everywhere, as well-spaced trees/ } \\
\text { shrubs like bushes in arid areas }\end{array}$ \\
\hline & C7 & 32 & $\begin{array}{l}\text { Spreading, the most abundant and } \\
\text { adapted taxon, favoured by warming and } \\
\text { dry soils }\end{array}$ & 2.2 & Slightly clumped & $\begin{array}{l}\text { Spreads in the most suitable areas; still in competition } \\
\text { with pine }\end{array}$ \\
\hline
\end{tabular}

\subsection{Forest dynamic trends according to anthracology}

The Abeurador anthracological sequence has not recorded the early postglacial expansion of pre-steppe woody species at the end of the Last Glacial Maximum. At other sites, Juniperus was the pioneer, creating conditions suitable for the migration of other groups of species, such as the Rhamnaceae and the Rosaceae, both suited to cold conditions, and then finally Pinus type sylvestris, before the arrival of deciduous Quercus (Heinz and Barbaza, 1998). Under a Mediterranean mountain climate (which may represent a current analogue of the Early Holocene conditions), in a progressive succession, Scots pine is indeed capable of spreading very quickly and rapidly supplanting juniper. Scots pine is, in turn, eliminated by pubescent oak, more resistant to extreme drought events (Poyatos et al., 2008).

At Abeurador, during the Younger Dryas, under cold and dry conditions, Scots pine was dominant across the landscape and probably spread almost everywhere. The differential factor that favoured Scots pine was probably the cold, not the drought. Indeed, at the beginning of the Early Holocene (Preboreal), the rapid increase of Juniperus at Abeurador, highly sensitive to the rise of temperatures and extremely resistant to drought (especially J. phœnicea), followed by Quercus deciduous, indicates probably a strong soil water deficit in the surroundings of the cave, due to the nature of the substratum. In C7 and C6, both warming and dry soils could explain the rapid disappearance of pine, leaving the dry, poor soils to junipers.

A similar succession has been observed at La Poujade (Millau, Aveyron) on the Causse Noir, at an altitude of $450 \mathrm{~m}$ (Krauss-Marguet,
1981), from the Mesolithic to the Iron Age. However, Scots pine there decreases gradually during the Preboreal and the Boreal, persisting a little until the Subboreal, in conditions undoubtedly less dry because they were more distant from Mediterranean influences. In some other areas in the south of France, palynology does not observe any expansion of Pinus during the Preboreal (Beaulieu et al., 1985). Such differences between sites in the representation of conifers during the Preboreal have already been noted by Henry et al. (2013).

Spatial differences in the various pathways by which species colonize are not surprising, as they depend on the contraction or expansion of their ranges and their different capacities for dispersal and maintenance in contrasting environments (Quézel and Médail, 2003). In the case of Abeurador, the differential situation for species seems due to the complex interaction between global climatic and local edaphic factors, which together determine water availability. Therefore, in the context of global warming, the main factors that governed the distribution of taxa were (i) their biotope preferences, such as temperature (altitude, exposure, topography) and soil conditions (geological substratum, topography, soil thickness, water availability), (ii) their dynamic successions involving the expansion of the range of certain species and competitive relationships with interspecific facilitation, tolerance or inhibition and (iii) the effects of climate change on all these conditions.

In the early Holocene, between the Early Mesolithic in C7 and the first level of the Middle Mesolithic in C6, variations between the major taxa indicate strong trends due to global warming. The main palaeoecological event is the strong decline of Scots pine, in favour of a vegetation more adapted to global warming, as evidenced by the quick 


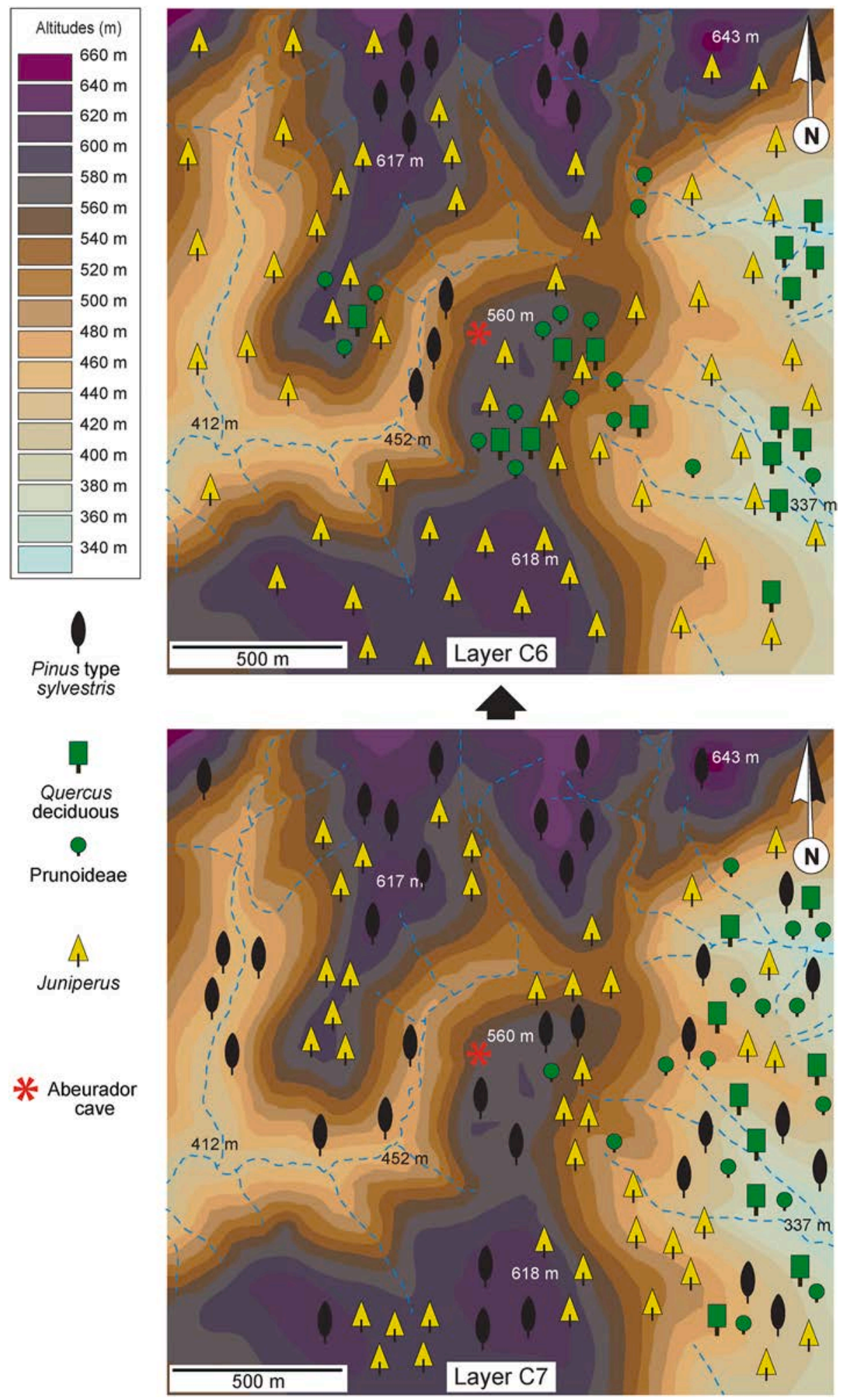

Fig. 8. Spatial evolution of postglacial vegetation around the Abeurador cave at the beginning of the Mesolithic (Preboreal), hypothesized according to anthracological frequencies and distribution indexes of the three main taxa in Layers C7 and C6 (red star: Abeurador cave; blue dotted lines: temporary streams; topographic base after IGN, 2019 www.geoportail.gouv.fr) (For interpretation of the references to colour in this figure legend, the reader is referred to the Web version of this article).

progression of juniper and the lesser growth of deciduous oak. According to the following levels, Pinus type sylvestris gradually disappears from the surroundings of the site, Juniperus undergoes a long phase of dominance and Quercus deciduous spreads gradually, to finally dominate during the Neolithic, accompanied by Prunoideae and
Mediterranean hardwood species. The persistence of oak populations in a refugium during the Younger Dryas permitted the rapid restart of oak forest expansion in the Early Holocene. 


\subsection{Spatial distribution of species based on distribution indexes}

In light of these trends and the distribution patterns deduced from the distribution indexes, we propose hypotheses on the spatial evolution of the three main taxa in the Abeurador surroundings during the Early Holocene, summarized in Table 6 and including a mapped restitution (Fig. 8).

- Pinus type sylvestris had the highest distribution indexes, with an increasing index from 2.48 in C7 to 4.22 in C6. Its frequency drops in C7 and especially in C6. Its increasing distribution index probably indicates that the Scots pine area has shrunk significantly, leaving only very localized population patches in the last zones favourable for its needs. This species avoids excess temperatures and needs a relative amount of moisture (Poyatos et al., 2008). It is likely that the pine found these conditions higher up in altitude and maybe also in the shade of the deep ravines surrounding the plateau, well rooted on the lower slopes on thick colluvium soils, in relatively moist and less windy conditions. This could explain an increasingly clumped distribution pattern for this taxon in steep decline.

- Quercus deciduous also has a rather high distribution index: 2.41 in C7, increasing to 3.06 in C6, indicating an increasing clumped distribution when it spreads further. The Prunoideae, linked to oak in a progressive dynamic, have almost the same index (3.28) in C6 as Quercus deciduous (the Prunoideae index in C7 was not statistically validated). It is likely that oak forests, which expanded during this phase, remained localized clusters. At this point, it is necessary to recall the complete story of deciduous oak at this site. Quercus deciduous arrived very early in the environment of the site, from southern primary refugia, during the Bølling-Allerød, due to a mild and humid climate. During the Younger Dryas in C8, the deciduous oak and Prunoideae areas shrunk as a 'secondary refugium'. Deciduous oak woodlands certainly occupied localized areas, in protected situations such as southern exposures and middle altitudes, probably sheltered under the mature conifer forests cover (pine and juniper being co-dominant in this period). It then respread slowly in the Early Holocene. In C7, we therefore assumed a distribution inherited from the previous period, extending over the suitable southern slopes. From there, the particular way in which this tree spreads involved the cover of other trees or shrubs, to protect the seedlings. In C6, when Scots pine forests shrink drastically, deciduous oak had deforested areas to conquer, with only the Prunoideae, such as Prunus spinosa, and junipers, as protective cover. If the deciduous oak moved, from C7 to C6, to a more clumped distribution, it is likely because during this second conquest oak woodlands colonized a mostly open environment. The oaks probably spread over the plateau in multiple small patches, from seed tree populations located in the south.

- Juniperus has the lowest distribution indexes, compared to the other species, decreasing from 2.2 in $\mathrm{C7}$ to 1.75 in C6, suggesting an increasingly even distribution as it spread. Several species may have existed, with different ecological requirements, but all were lightdemanding and adapted to drought. According to seed/fruit findings, Juniperus communis cf. subsp. nana, J. sabina, J. communis cf. subsp. communis and $J$. thurifera, registered from the Middle Magdalenian, remain abundant in this transition period (Vaquer and Ruas, 2009). The first two were the most abundant and the most suited during the previous cold periods (from Oldest Dryas C10b to Younger Dryas C8, alongside Arctostaphylos uva-ursi and Hippophae rhamnoides, and were interpreted as shrubby pioneer-steppe vegetation. These lasted for some time and were still abundant in C7. From C6, they sharply decreased. Despite carpology showing that J. sabina and $J$. thurifera were still present until the end of the Middle Mesolithic, they had probably been replaced by more thermophilous species, such as $J$. communis subsp. communis, J. phønicea and $J$. oxycedrus (the three species present today), although the latter two were not found in charred seeds/fruits. Juniperus thurifera (currently rare in France), may have played a significant role, as its fruits were present notably in the Early Holocene (from C7 to C3). This small tree (up to $12 \mathrm{~m}$ in height, very slow-growing at altitudes ranging from 140 to $3000 \mathrm{~m}$ and resistant to continental climatic extremes) does not bear fruits until the age of 50 (Widmann, 1950). It may have belonged to the open Scots pine forest, as well as to the oak forest. Because of its adaptation to extremely cold winters, it is considered to be the Juniperus species most likely to occur in pre-steppe forests during Late glacial periods in the western Mediterranean, associated with Pinus sylvestris, while J. phrnicea was better adapted to extremes of drought in southern regions (Quézel and Médail, 2003). However, $J$. thurifera cannot compete with faster-growing species, such as Pinus sylvestris and Quercus pubescens, except in high drought conditions (Widmann, 1950), or in a situation of intensive grazing (Gauquelin et al., 1999). Whatever the species, Juniperus has indeed been dominated by Pinus type sylvestris during the Younger Dryas and by Quercus deciduous during the Atlantic. It can probably be considered that brutal droughts such as those of the Oldest and Younger Dryas, even more so than cold climate, are at the origin of the successive spreads of junipers. In the Early Holocene, when junipers spread the most, probably almost all species of junipers, including all heliophilic and xerophilic, would have had the ability to colonize large areas, as transitional formations, pending the arrival of tree species. Heat-demanding juniper species probably gradually replaced cold-resistant species.

In C7, maybe still in competition with pines, junipers appear to have been more clumped than later in C6, while their frequency doubles as they spread into the newly opened spaces. Juniperus probably colonized more quickly than Quercus deciduous the open areas left free by the pine recession, especially on the flats of the plateau system, the most exposed to severe climate variations, with poor but suitable soils. In any case, it can be observed, especially in dry mountainous or Mediterranean areas, that juniper shrubs are generally well spaced, as are bushes in arid areas. The Juniperus distribution index in C6, a little over 1, is the closest to a uniform distribution in our data. This regularity could be due to root competition for water and nutrients. Each bush needs a large area to collect the little moisture present and tends to inhibit root regrowth in its immediate vicinity. However, this distribution pattern does not depend only on the species. Research on current desert shrub species has shown that, depending on the age of the individuals, they can first have a clumped distribution at the seedling stage (grouped around their parents), then a random distribution (when competition increases), then a uniform distribution at the old shrub stage, when competition is at its peak (Molles and Sher, 2019). Although this parallel is not sufficient to infer that the juniper populations at Abeurador grew older between C7 and C6, it is likely that they spread almost everywhere over the plateau and reached an advanced age during their long expansion period of several thousand years. Throughout the Middle Mesolithic, junipers dominated, then decreased after the Boreal because their niches were shaded out by oaks.

\section{Conclusion}

Using the spatial distribution of charcoals in two archaeological layers, we hypothesized that the frequency distribution of each taxon (per grid square) may represent its sampling distribution in the past environment. Distribution indexes linked to theoretical distributional patterns of vegetation were calculated, then used to propose assumptions about the spatial location of woodlands around the Abeurador cave during the Early Holocene, in accordance with the ongoing dynamics due to global climate change, local ecological particularities (edaphic drought, rugged topography) and competitive relationships of taxa. The 
spatial distribution of four major taxa was mapped by hypothesis.

In this study, the method was applied to very abundant, scattered charcoal fragments (excluding concentrations), originating from fuelwood in a long-term occupied habitat context, sampled by square and using wet-sieving, according to the most rigorous anthracological methods currently available. The method requires significant sampling and analysis, but not all sites yield the abundance of material necessary to obtain more than 100 or 200 fragments per square. The very good spatial distribution of anthracological information is not specific to prehistoric habitats; however, the more structured the site (as in the case of highly organized human communities), the greater the methodological effort required to define adequate charcoal deposits.

Nowadays, anthracological datasets can provide accurate and reliable information, not only on the overall composition of past forests and their transformations over time but also on their spatial distribution in the surroundings of a site, shedding light on more specific palaeoecological issues. We believe that anthracology has reached a possible level of methodological precision that should make it a reference discipline in palaeoecology.

According to Rull (2010), 'a palaeoecologist is not simply a palaeoscientist whose data may be of interest for ecology, but an ecologist working on another time scale with different methods. Ecology and palaeoecology are only different approaches with ' $a$ common objective, which is the ecological understanding of the biosphere'. The mains aims of 'ecological palaeoecology, rather than merely unravelling past climatic and environmental trends, are to reconstruct ecosystem dynamics, to understand their environmental drivers and underlying mechanisms, and to provide empirical data for testing ecological hypotheses' (Rull, 2014). Rull (2010) also recommends the refinement of quantitative methodologies to increase the objectivity of interpretations.

An anthracological approach applied to palaeoecology is indeed able to provide complete, repeatable and consistent data if it is supported by a constant methodological requirement, starting with strict field sampling rules and the analysis of sufficient quantities of material. From there, a vast field of unknowns can be opened up. Anthracological data can provide a great deal of information on past vegetation.

However, the lines of thought we propose are a very demanding approach, as archaeological charcoal can feed into equally interesting ethnographic and palaeoecological questions.

First, ethnographic issues that take place in the habitat or artisanal structures, such as fire-related behaviours and practices, need to be studied with great critical rigour of the available material and information. In particular, short-term deposits may be meaningless. Ethnographic issues that take place in the environment, such as forest management vs agropastoral practices, can find important insights through anthracology. They are only one particular aspect of palaeoecological approach and are studied according to charcoal scatters, in the same way as global changes.

Secondly, in the field of palaeoecology, well-sampled charcoals are an extraordinarily reliable and representative material. It is because, and not despite, the fact that firewood has passed through human hands, day after day, and through repeated sampling of vegetation in a relatively limited area, that wood is representative of the vegetation. And because wood has gone through an amazing synthetic stochastic process - combustion, followed by processes of dispersal and relative destruction of the remains - the information remaining in the archaeological site can be studied without too much analytical effort.

We do not pretend that no bias can exist in the datasets, but the random variations in the information are by no means a problem. Shortterm deposits in hearths and other concentrated deposits are easily avoided, through sampling choices and a posteriori spatial analysis in layers. Sometimes poor, disturbed or very heterogeneous layers must also be studied carefully. If unavoidable biases are found in the representation of past vegetation, they probably occurred by processes of an equally stochastic nature as wood gathering or combustion processes. One can think of the particular effects of combustion on certain species that have not yet been demonstrated (such as the possible calorific interactions between low-density and high-density woods). As we mentioned, wood collection behaviours could systematically distort the representation of certain major species, for example according to their physiognomic state, at equal biomass (e.g. high forest versus coppice, or pioneer stage vs. mature forest). Furthermore, in these latter examples, since the size of the stems determines the aeration of the fire (the main factor in ash reduction), burning small branches would leave less charcoal than burning an equal weight of large logs. These deformation factors would benefit from being modelled.

Once the sampling and analysis has been completed, present-day ecology is an essential support for interpretations of the past. The abundance of ecological literature is an obstacle and would require greater collaboration between ecologists and palaeoecologists. However, we must also be willing to go beyond what we know concerning woodland communities. We believe that current vegetation analogues are not sufficient to describe ecosystems of the past. The place of some species in ecosystems has changed because the trajectories of species in ecological successions depend on their past history in each location and because of the profound change in living conditions. We believe that anthracology, which perceives an environment of proximity, can particularly fuel these issues.

\section{Declaration of competing interest}

The authors declare that they have no known competing financial interests or personal relationships that could have appeared to influence the work reported in this paper.

\section{Acknowledgements}

We thank Eleni Asouti and Jill Cucchi for their help in improving the English of the manuscript and two anonymous reviewers for their highly constructive comments.

\section{References}

Alcalde, G., Saña, M., 2017. Mesolithic occupations in Bauma de Serrat del Pont, 7500-6500 cal BC: new data on the last hunter-gatherer populations in northeast Iberia. Mesolithic Miscellany 25 (1), 3-10.

Alcolea Gracia, M., 2017. Paisaje vegetal y gestión de recursos leñosos durante la transición Epipaleolítico-Neolítico en el valle del Ebro. Aportaciones desde la antracología. Ph.D. Thesis. Universidad Zaragoza.

Aranbarri, J., Alcolea, Marta, Badal, E., Vila, S., Allué, E., Iriarte-Chiapusso, M.J., Sebastián, M., Magri, D., González-Sampériz, P., 2020. Holocene history of aleppo pine (Pinus halepensis mill.) woodlands in the Ebro basin (NE Spain): climate-biased or human-induced? Rev. Palaeobot. Palynol. 279. Article 104240.

Asouti, E., Austin, P., 2005. Reconstructing woodland vegetation and its exploitation by past societies, based on the analysis and interpretation of archaeological wood charcoal macro-remains. Environ. Archaeol. 10, 1-18.

Badal Garcia, E., 1990. Méthode de prélèvement et paléoécologie du Néolithique d'après les charbons de bois de la Cova de les Cendres (Alicante Espagne). In: Hackens, T., Munaut, A.V., Till, Cl. (Eds.), Wood and Archaeology. Bois et archéologie. First European Conference, Louvain-la-Neuve, Belgique, , Oct. 2nd-3rd 1987. PACT. 22, pp. 231-224.

Badal Garcia, E., 1992. L'anthracologie préhistorique: à propos de certains problèmes méthodologiques. In: Vernet, J.-L. (Ed.), Les charbons de bois, les anciens écosystèmes et le rôle de l'Homme, Colloque International de Montpellier, 10-13 sept. 1991. Bull. de la Société botanique de France, Actualités Botaniques. 139 (2/3/ 4), pp. 167-189.

Badal, E., Carrión Marco, Y., 2001. Del Glaciar al Interglaciar : los paisajes vegetales a partir de los restos carbonizados hallados en las cuevss de Alicante. In: Bonilla, Villaverde (Ed.), V. (coord.), De neandertales a cromañones: el inicio del poblamiento en las tierras valencianas. Universitat de Valencia.

Beaulieu de, J.-L., Pons, A., Reille, M., 1985. Recherches pollenanalytiques sur l'histoire tardiglaciaire et holocène de la vegetation des Monts d'Aubrac (Massif Central, France), Rev, Palaeobot. Palynol. 44, 37-80.

Bourquin Mignot, C., Brochier, J.E., Chabal, L., Crozat, S., Fabre, L., Guibal, F., Marinval, P., Richard, H., Terral, J.-F., Théry-Parisot, I., 1999. In: Ferdière, A. (Ed.), La Botanique, Collection Archéologiques. Errance.

Buxó, R., 2008. Les llavors i els fruits. In: Alcalde, G., Saña, M. (Eds.), Procés d'ocupació de la Bauma del Serrat del Pont (la Garrotxa) entre 7400 i 5480 cal AC, 48-49, 69-70, 84. Museu Comarcal de la Garrotxa, Olot. 
Chabal, L., 1982. Méthodes de prélèvement des bois carbonisés protohistoriques pour l'étude des relations homme-végétation. Diplôme d'Études Approfondies, University of Montpellier (France).

Chabal, L., 1990. L'étude paléoécologique de sites protohistoriques à partir des charbons de bois: la question de l'unité de mesure. Dénombrement de fragments ou pesées? In: Hackens, T., Munaut, A.V., Till, Cl (Eds.), Wood and Archaeology. Bois et archéologie. First European Conference, Louvain-la-Neuve, Belgique, Oct. 2nd-3rd 1987. PACT. 22, pp. 189-205.

Chabal, L., 1991. L'Homme et l'évolution de la végétation méditerranéenne, des âges des métaux à la période romaine : recherches anthracologiques théoriques, appliquées principalement à des sites du Bas-Languedoc. Ph.D. Thesis. University of Montpellier (France).

Chabal, L., 1992. La représentativité paléo-écologique des charbons de bois archéologiques issus du bois de feu. In: Vernet, J.-L. (Ed.), Les charbons de bois, les anciens écosystèmes et le rôle de l'Homme, Colloque International de Montpellier, 10-13 sept. 1991. Bull. de la Société botanique de France, Actualités Botaniques. 139 (2/3/4), pp. 213-236.

Chabal, L., 1997. Forêts et sociétés en Languedoc (Néolithique final, Antiquité tardive) l'anthracologie, méthode et paléoécologie, vol. 63. Documents d'Archéologie Française.

Chabal, L., 2001. Les Potiers, le bois et la forêt à Sallèles d'Aude (I-IIIe s. ap. J.-C.). In: Laubenheimer, F. (Ed.), 20 ans de recherches à Sallèles d'Aude: le Monde des potiers gallo-romains, Colloque 27-28 Sept. 1996, Sallèles d'Aude. Presses Universitaires Franc-Comtoises, Série Amphores, pp. 93-110.

Chabal, L., Laubenheimer, F., 1994. L'atelier gallo-romain de Sallèles d'Aude : les potiers et le bois. In: Actes des XIVe Rencontres Internationales d'Archéologie et d'Histoire d'Antibes Terre cuite et Société : la céramique, document technique, économique, culturel, APDCA, 21-23 Oct. 1993, pp. 99-129. Juan-les-Pins.

Chabal, L., Vaschalde, C., (in press). Évolution des espaces forestiers néolithiques et impact du pâturage en forêt : l'apport de l'anthracologie, in: C. Manen (Ed.). Le Tai (Remoulins, Gard). Premières sociétés agropastorales du Languedoc méditerranéen (6e-3e millénaire avant notre ère), Toulouse, Archives d'Ecologie Préhistorique.

Chrzazvez, J., Théry-Parisot, I., Fiorucci, G., Terral, J.-F., Thibaut, B., 2014. Impact of post-depositional processes on charcoal fragmentation and archaeobotanical implications: experimental approach combining charcoal analysis and biomechanics. J. Archaeol. Sci. 44 (1), 30-42.

Curt, T., Marsteau, C., 1997. La gestion des taillis de chênes vert et pubescent dans les garrigues du Gard : analyse du milieu et de la productivité des peuplements. Ingénieries EAT 11, 71-84.

Figueiral, I., Terral, J.-F., 2002. Late Quaternary refugia of Mediterranean taxa in the Portuguese Estremadura: charcoal based palaeovegetation and climatic reconstruction. Quat. Sci. Rev. 21, 549-558.

Gauquelin, T., Bertaudière, V., Montes, N., Badri, W., Asmode, J.-F., 1999. Endangered stands of thuriferous juniper in the western Mediterranean basin: ecological status, conservation and management. Biodivers. Conserv. 8, 1479-1498.

Heinz, C., 1990a. Dynamique des végétations holocènes en Méditerranée occidentale d'après l'anthracoanalyse des sites préhistoriques: Méthodologie et Paléoécologie. Paleobiol. Cont. XVI (2)

Heinz, C., 1990b. Méthodologie et paléoécologie du gisement préhistorique de l'Abeurador (Hérault) au passage Mésolithique/Néolithique, d'après l'analyse des charbons de bois: premiers résultats. In: Hackens, T., Munaut, A.V., Till, Cl. (Eds.), Wood and Archaeology. Bois et archéologie. First European Conference, Louvain-laNeuve, Belgique, 2-3 Oct. 1987. PACT. 22, 22, pp. 219-229.

Heinz, C., Barbaza, M., 1998. Environmental changes during the late glacial and postglacial in the central Pyrenees (France): new charcoal analysis and archaeological data. Rev. Palaeobot. Palynol. 104, 1-17.

Heinz, C., Ruas, M.-P., Vaquer, J., 1992. La grotte de 1'Abeurador (Félines-Minervois, Hérault): paléoécologie d'après l'anthracologie et la carpologie. In: Vernet, J.-L. (Ed.), Charcoal Ancient Ecosystems and Human Impact. Colloque International Montpellier, 10-13 Sept. 1991. Bull. de la Société botanique de France, Actualités Botaniques. 139 (2/3/4), pp. 465-482.

Heinz, C., Thiébault, S., 1998. Characterization and palaeoecological significance of archaeological charcoal assemblages during Late and Post-Glacial phases in southern France. Quat. Res. 50 (1), 56-68.

Henry, A., 2011. Paléoenvironnements et gestion du bois de feu au Mésolithique dans le sud-ouest de la France : anthracologie, ethno-archéologie et expérimentation. Ph.D. Thesis. University of Nice-Sophia Antipolis, (France).

Henry, A., Valdeyron, N., Bouby, L., Théry-Parisot, I., 2013. History and evolution of Mesolithic landscapes in the Haut-Quercy: new charcoal data from archaeological contexts. Holocene 23 (1), 127-136.

Jamet, M., 2001. Approche par la modélisation du complexe de potiers de Sallèlesd'Aude ", 20 ans de recherches à Sallèles-d'Aude. In: Laubenheimer, F. (Ed.), Le Monde des potiers gallo-romains, Colloque International Sallèles-d'Aude, 27-28 Sept. 1996. Annales Littéraires de l'Université de Besançon, Série Amphores., pp. 257-284

Jolain, R., 1961. Essai sur les taillis de chêne vert et de chêne pubescent. Rev. For. Fr. (Nancy) 2, 81-89.

Kabukcu, C., 2018. Identification of woodland management practices and tree growth conditions in archaeological fuel waste remains: a case study from the site of Çatalhöyük in central Anatolia, Turkey. Quat. Int. 463, 282-297.

Kabukcu, C., Chabal, L., This issue. Sampling and quantitative analysis methods in anthracology from archaeological contexts: achievements and prospects, Quat. Int.

Kaufman, D., et al., 2020. A Global Database of Holocene Paleotemperature Records. Scientific Data. https://www.nature.com/articles/s41597-020-0445-3.

Krauss-Marguet, I., 1981. Analyse anthracologique du gisement postglaciaire de la Poujade (Millau, Aveyron). Paleobiol. Cont. 12 (1), 93-110.
Langlais, M., Costamagno, S., Laroulandie, V., Pétillon, J.-M., Discamps, E., Mallye, J.-B., Cochard, D., Kuntz, D., 2012. The evolution of Magdalenian societies in South-West France between 18,000 and 14,000 cal BP: changing environments, changing tool. Quat. Int. 272/273, 138-149.

Martínez Varea, C.M., Badal García, E., 2018. Plant use at the end of the Upper Palaeolithic: archaeobotanical remains from Cova de les Cendres (Teulada-Moraira, Alicante, Spain). Veg. Hist. Archaeobotany 27, 3-14.

Mauri, A., Davis, B.A.S., Collins, P.M., Kaplan, J.O., 2015. The climate of Europe during the Holocene: a gridded pollen-based reconstruction and its multi-proxy evaluation. Quat. Sci. Rev. 112, 109-127.

Mistrot, V., 2001. Contribution des micro-mammifères de l'Abeurador à la connaissance de l'évolution des paysages tardiglaciaires et holocènes en Languedoc Roussillon. Thèse de Doctorat de l'Université de Paris 1, Panthéon Sorbonne (France) it is a thesis.

Molles Jr., M.C., Sher, A.A., 2019. Ecology: Concepts and Applications, eighth ed. McGraw-Hill Education, New York.

Monteiro, P.D., 2013. Wood charcoal analysis of mesolithic archaeological contexts from Portugal: state of the art. Revista Arkeogazte 3, 51-62.

Petit, R.J., Brewer, S., Bordács, S., Burg, K., Cheddadi, R., Coart, E., Cottrell, J., Csaikl, U. M., van Dam, B.C., Deans, J.D., Espinel, S., Fineschi, S., Finkeldey, R., Glaz, I., Goicoechea, P.G., Jensen, J.S., König, A.O., Lowe, A.J., Madsen, S.F., Mátyás, G., Munro, R.C., Popescu, F., Slade, D., Tabbener, H., de Vries, S.M.G., Ziegenhagen, B., Beaulieu de, J.-L., Kremer, A., 2002. Identification of refugia and postglacial colonization routes of European white oaks based on chloroplast DNA and fossi pollen evidence. For. Ecol. Manag. 156, 49-74.

Poyatos, R., Llorens, P., Piñol, J., Rubio, C., 2008. Response of Scots pine (Pinus sylvestris L.) and pubescent oak (Quercus pubescens Willd.) to soil and atmospheric water deficits under Mediterranean mountain climate. Ann. For. Sci. 65, 306-318.

Pulliam, H.R., 2002. On the relationship between niche and distribution. Ecol. Lett. 3 (4), 349-361.

Quézel, P., Médail, F., 2003. Écologie et biogéographie des forêts du bassin méditerranéen. Collection Environnement, Elsevier, Paris.

Rasmussen, S.O., Bigler, M., Blockley, S.P., Blunier, T., Buchardt, S.L., Clausen, H.B., Cvijanovic, I., Dahl-Jensen, D., Johnsen, S.J., Fischer, H., Gkinis, V., Guillevic, M., Hoek, W.Z., Lowe, J.J., Pedro, J.B., Popp, T., Seierstad, I.K., Steffensen, J.P., Svensson, A.M., Vallelonga, P., Vinther, B.M., Walker, M.J.C., Wheatley, J.J., Winstrup, M., 2014. A stratigraphic framework for abrupt climatic changes during the Last Glacial period based on three synchronized Greenland ice-core records: refining and extending the INTIMATE event stratigraphy. Quat. Sci. Rev. 106, 14-28.

Rey, G., Hermeline, M., 1994. In: L'Europe et la Forêt (Eurofor, ONF, Parlement européen), vol. 2. European Parliament.

Ribeiro, M.M., Roque, N., Ribeiro, S., Gavinhos, C., Castanheira, I., Quinta-Nova, L., et al., 2019. Bioclimatic modeling in the Last Glacial Maximum, Mid-Holocene and facing future climatic changes in the strawberry tree (Arbutus unedo L.). PloS One 14 (1), e0210062. https://doi.org/10.1371/journal.pone.0210062.

Roiron, P., Chabal, L., Figueiral, I., Terral, J.-F., Ali, A., 2013. Palaeobiogeography of Pinus nigra arn. subsp. salzmannii (dunal) franco in the North-western Mediterranean basin, based on macroremains. Rev. Palaeobot. Palynol. 194, 1-11.

Rull, V., 2010. Ecology and palaeoecology: two approaches, one objective. Open Ecol. J. $3,1-5$.

Rull, V., 2014. Ecological palaeoecology: a missing link between ecology and evolution. Collect. Bot. 33 (1), 65-73

Théry-Parisot, I., 2001. Économie du combustible au Paléolithique. Anthracologie, Expérimentation, Taphonomie, CEPAM. CNRS Editions.

Théry-Parisot, I., Chabal, L., Chrzavzez, J., 2010a. Anthracology and taphonomy, from wood gathering to charcoal analysis. A review of the taphonomical processes modifying anthracological assemblages in archaeological contexts. Palaeogeogr. Palaeoclimatol. Palaeoecol. 291, 142-153.

Théry-Parisot, I., Chabal, L., Ntinou, M., Bouby, L., Carre, A., 2010b. Du bois aux charbons de bois : approche expérimentale de la combustion. From wood to wood charcoal: an experimental approach to combustion. In: Théry-Parisot, I., Chabal, L., Costamagno, S. (Eds.), Actes de la table ronde internationale « Taphonomie de la combustion des résidus organiques et des structures de combustion en contexte archéologique » 27-29 mai 2008, Valbonne. Palethnology, vol. 2, pp. 81-93.

Thiébault, S., 1997. Early-Holocene vegetation and the human impact in central Provence (Var, France): charcoal analysis of the Baume de Fontbrégoua. Holocene 7 (3), 343-349.

Uzquiano, P., Casas-Gallego, M., Mingo, A., Barba, J., Yravedra, J., 2016. Vegetation, climate and human settlement interactions at the late Mesolithic site of Cueva Blanca (Hellín, Albacete, SE Spain). Holocene 26 (1), 102-112.

Vaquer, J., Barbaza, M., 1987. Cueillette ou horticulture mésolithique : la Balma de l'Abeurador. In: Guilaine, J., Courtin, J., Roudil, J.-L., Vernet, J.-L. (Eds.), Premières Communautés Paysannes de la Méditerranée occidentale. Actes du colloque de Montpellier 26-29 av. 1983. CNRS Ed., Paris, pp. 231-242.

Vaquer, J., Ruas, M.-P., 2009. La grotte de l'Abeurador Félines-Minervois (Hérault) : occupations humaines et environnement du Tardiglaciaire à l'Holocène. In: Collectif, De Méditerranée et d'ailleurs. Mélanges offerts à Jean Guilaine. Archives d'Écologie Préhistorique, Toulouse, pp. 761-792.

Vernet, J.-L., Thiébault, S., 1987. An approach to northwestern Mediterranean recent prehistoric vegetation and ecologic implications. J. Biogeogr. 14, 117-127.

Vidal-Matutano, P., 2016. Firewood and hearths: middle palaeolithic woody taxa distribution from el salt, stratigraphic unit xb (eastern iberia). Quat. Int. 457, 74-84.

Widmann, M., 1950. Le Genévrier thurifère dans les Hautes-Alpes. Rev. Géogr. Alp. 38 (3), 493-508. 